\title{
Krzysztof Stachowiak
}

Uniwersytet im. Adama Mickiewicza w Poznaniu

Instytut Geografii Społeczno-Ekonomicznej i Gospodarki Przestrzennej

e-mail:krst@amu.edu.pl

\section{Problemy metodologiczne badania sektora kreatywnego ${ }^{1}$}

\begin{abstract}
Zarys treści: $\mathrm{W}$ artykule dokonano identyfikacji i charakterystyki głównych problemów metodologicznych badania sektora kreatywnego. W pierwszej części uwagę poświęcono zagadnieniom semiotycznym związanym $z$ podstawowymi pojęciami, zwłaszcza $z$ ich definiowaniem, klasyfikacją i tłumaczeniem. W drugiej części artykułu przedstawiono wyniki empirycznego badania zbioru prac dotyczących sektora kreatywnego. Pozwoliły one scharakteryzować najważniejsze cechy metodologiczne dotychczasowych badań nad sektorem kreatywnym, takie jak przedmiot tych badań, poziomy analizy, skala przestrzenna, stosowane metody naukowe, rodzaj i źródła wykorzystywanych danych oraz charakter wiedzy o sektorze kreatywnym wytworzonej w efekcie tych badań.
\end{abstract}

Słowa kluczowe: sektor kreatywny, metodologia, metody badań

\section{Wstęp}

Celem artykułu jest identyfikacja i charakterystyka głównych problemów metodologicznych badania sektora kreatywnego. W pierwszej części uwagę poświęcono zagadnieniom semiotycznym związanym z podstawowymi pojęciami, zwłaszcza $z$ ich definiowaniem, klasyfikacją i tłumaczeniem. Tym ostatnim problemem zajęto się szczególnie dokładnie, gdyż nieadekwatne tłumaczenia są zasadniczą przyczyną konfuzji i nieporozumień wśród badaczy sektora kreatywnego, a także wpływają istotnie na konceptualizację i uogólnianie wyników badań. W drugiej części artykułu przedstawiono wyniki empirycznego badania zbioru prac dotyczących sektora kreatywnego. Pozwoliły one scharakteryzować główne cechy metodologiczne dotychczasowych badań nad sektorem kreatywnym, takie jak przedmiot tych badań, poziomy analizy, skala przestrzenna, stosowane metody naukowe, rodzaj i źródła wykorzystywanych danych oraz charakter wiedzy o sektorze kreatywnym wytworzonej w efekcie tych badań. Przeanalizowano 209 prac

1 Badania zostały sfinansowane ze środków Narodowego Centrum Nauki przyznanych na podstawie decyzji numer DEC-2011/03/D/HS4/01662. 
opublikowanych w latach 1995-2014, których szczegółowy wykaz znajduje się w załączniku. Ich dobór miał w zasadzie charakter arbitralny, jednak starano się zachować reprezentatywne cechy badanej zbiorowości. W związku z tym przyjęto następujące założenia, według których dobierano prace: (1) preferowano empiryczny charakter pracy, które w badanej próbie tego rodzaju prace stanowiły $79 \%$ całej zbiorowości; (2) prace dotyczyć miały głównie sektora kreatywnego jako całości, badanego jednak w różnych aspektach, takich jak np. miasta kreatywne, kreatywna gospodarka, klasa kreatywna, branże kreatywne; (3) wybrane do badania prace miały odzwierciedlać zróżnicowanie geograficzne autorów oraz obszarów będących przedmiotem danej pracy. Choć opracowania badaczy brytyjskich, australijskich czy amerykańskich wiodą prym w ogólnoświatowych badaniach poświęconych sektorowi kreatywnemu, publikacje wybrane do badania napisane były przez autorów afiliowanych w 22 krajach (Australia, Austria, Czechy, Dania, Finlandia, Francja, Grecja, Hiszpania, Holandia, Irlandia, Izrael, Kanada, Niemcy, Polska, RPA, Singapur, Szwajcaria, Szwecja, USA, Węgry, Wielka Brytania, Włochy). Blisko $1 / 3$ prac stanowiły badania trzech wspomnianych wyżej krajów. Wzięto również pod uwagę polskie badania, starając się zebrać możliwie dużą i zróżnicowaną reprezentację. Badano prace, które zostały napisane w języku angielskim lub polskim.

\section{Semantyczne oraz pragmatyczne problemy z podstawowymi pojęciami i odpowiadającymi im terminami}

\section{Problemy z definicją i klasyfikacją sektora kreatywnego}

Operacjonalizacja badań dotyczących sektora kreatywnego nie jest łatwa ze względu na trudności w identyfikacji tego sektora. Wzrost znaczenia działalności kreatywnych i związanych z szeroko pojętą kulturą idzie bowiem w parze ze spadkiem znaczenia tzw. fordowskiego modelu produkcji (polegającego - w najbardziej ogólnym ujęciu - na masowej produkcji standaryzowanych dóbr) i związanych z nim tradycyjnych klasyfikacji działalności gospodarczej. Zmienia się również charakter przedsiębiorstw, które można określić jako kreatywne: wzrasta rola małych, mobilnych firm, funkcjonujących w ramach sieci rozbudowanych łańcuchów powiązań. Semiotyczne wartości produktów, takie jak np. marka, wzornictwo produktu czy jego symboliczne znaczenie, stają się niemal równie istotne, jak ich wartości użytkowe - Lash i Urry (1994, s. 61) nazywają to współczesne zjawisko semiotyzacją konsumpcji. Wszystko to powoduje, że działalności kreatywne $z$ trudem poddają się „sztywnym” kryteriom klasyfikacyjnym, co z kolei pociąga za sobą niejednoznaczność i wymieszanie używanych w literaturze pojęć i klasyfikacji (Stryjakiewicz, Stachowiak 2010).

Hesmondhalgh i Pratt (2005), a także Musterd i in. (2007) twierdzą, że najwcześniej w anglosaskiej literaturze naukowej pojawił się termin cultural industries, natomiast od początku obecnego stulecia nastąpiło przesunięcie preferencji 
autorów w kierunku pojęcia creative industries. Szerszą dyskusję na temat tej zmiany znaleźć można w pracach Cunninghama (2002) i Garnhama (2005). Z kolei rozwój mediów i nowych technologii informacyjno-komunikacyjnych pociągnął za sobą wprowadzenie do literatury takich pojęć, jak digital industries oraz copyright industries. Szczegółowe omówienie różnic między zakresem przedmiotowym wymienionych wyżej pojęć zawarte jest w pracy Hartleya (2005), której próbą syntezy jest tabela 1 .

Oprócz powyższych problemów klasyfikacyjnych w polskiej literaturze naukowej pojawiają się do tego trudności związane z tłumaczeniem angielskiej terminologii na język polski. O ile w języku angielskim terminy cultural industries, creative industries czy creative economy są powszechnie przyjęte, o tyle ich polskie odpowiedniki zależą od inwencji tłumacza (lub jej braku). „Przemysł kulturalny”, „przemysł kulturowy”, „przemysł kultury”, „przemysły kultury”, „przemysły kreatywne”, „sektor kreatywny”, „sektor kultury”, „działalności kreatywne” - to bodaj najczęściej pojawiające się w literaturze polskiej odpowiedniki angielskich terminów. Problem polega na tym, że polskojęzyczne terminy odnoszące się do sektora kreatywnego nie do końca odpowiadają pojęciom obcojęzycznym. Dla jasności warto przypomnieć, że pojęcie to „wynik czynności myślowej, dotyczącej określonego przedmiotu rozpatrywanego pojedynczo lub jako wchodzącego w skład określonej klasy przedmiotów, a polegający na uświadomieniu przez myślącego charakterystycznej cechy lub zespołu charakterystycznych cech tego przedmiotu” (Nowicki 1986, s. 25). Natomiast nazwa lub termin to „znak słowny, który przyporządkowujemy określonemu pojęciu, a co zatem idzie, i przedmiotowi, którego to pojęcie dotyczy" (Nowicki 1986, s. 30). Analiza semantycz-

Tabela 1. Porównanie różnych klasyfikacji działalności związanych z sektorem kreatywnym

\begin{tabular}{|c|c|c|c|c|}
\hline $\begin{array}{c}\text { Nazwa } \\
\text { działalności }\end{array}$ & $\begin{array}{c}\text { Działalności } \\
\text { twórcze } \\
\text { (creative industries) }\end{array}$ & $\begin{array}{l}\text { Działalności zwią- } \\
\text { zane z prawami } \\
\text { autorskimi } \\
\text { (copyright industries) }\end{array}$ & $\begin{array}{l}\text { Działalności kultu- } \\
\text { ralne } \\
\text { (cultural industries) }\end{array}$ & $\begin{array}{c}\text { Działalności zwią- } \\
\text { zane z technologia- } \\
\text { mi cyfrowymi } \\
\text { (digital industries) }\end{array}$ \\
\hline $\begin{array}{l}\text { Kryterium } \\
\text { identyfikacji }\end{array}$ & $\begin{array}{l}\text { Definiowane } \\
\text { przez charakter } \\
\text { nakładów pracy } \\
\text { (twórcze jednost- } \\
\text { ki) }\end{array}$ & $\begin{array}{l}\text { Definiowane przez } \\
\text { charakter two- } \\
\text { rzonych zasobów } \\
\text { i rezultatów pracy }\end{array}$ & $\begin{array}{l}\text { Definiowane przez } \\
\text { publiczny charakter } \\
\text { funkcji i źródeł finan- } \\
\text { sowania }\end{array}$ & $\begin{array}{l}\text { Definiowane przez } \\
\text { kombinację nowo- } \\
\text { czesnej technologii } \\
\text { z działalnością } \\
\text { twórczą }\end{array}$ \\
\hline $\begin{array}{c}\text { Rodzaje } \\
\text { działalności }\end{array}$ & $\begin{array}{l}\text { Reklama } \\
\text { Architektura } \\
\text { Wzornictwo } \\
\text { Oprogramowanie } \\
\text { komputerowe, } \\
\text { gry elektroniczne } \\
\text { Film i TV } \\
\text { Muzyka } \\
\text { Działalność wy- } \\
\text { dawnicza } \\
\text { Sztuki piękne }\end{array}$ & $\begin{array}{l}\text { Sztuka komercyjna } \\
\text { Film i wideo } \\
\text { Dzieła muzyczne } \\
\text { Działalność wydaw- } \\
\text { nicza } \\
\text { Fonografia } \\
\text { Oprogramowanie } \\
\text { i systemy przetwa- } \\
\text { rzania danych }\end{array}$ & $\begin{array}{l}\text { Muzea i galerie } \\
\text { Sztuki plastyczne } \\
\text { Rzemiosło artystycz- } \\
\text { ne } \\
\text { Szkolnictwo arty- } \\
\text { styczne } \\
\text { RTV } \\
\text { Kinematografia } \\
\text { Biblioteki }\end{array}$ & $\begin{array}{l}\text { Film i wideo } \\
\text { Fotografia } \\
\text { Gry elektroniczne } \\
\text { Fonografia } \\
\text { Uzyskiwanie, } \\
\text { przetwarzanie } \\
\text { i przechowywanie } \\
\text { informacji }\end{array}$ \\
\hline
\end{tabular}

Źródło: Hartley (2005, s. 30), Stryjakiewicz, Stachowiak (2010, s. 21), ze zmianami. 
nych i pragmatycznych problemów związanych z podstawowymi pojęciami i ich polskimi nazwami przeprowadzona zostanie nieco dalej. Aby móc tego dokonać konieczne jest krótkie zarysowanie genezy pojęcia sektora kreatywnego. Na koniec wysunięta zostanie propozycja mająca na celu ujednolicenie terminologii.

Należy zaznaczyć, że celem poniższej analizy nie jest dokonanie przeglądu definicji ani dyskusja nad nimi. Takowe można znaleźć w literaturze - przykładowo Ilczuk (2012, s. 98-111) dokonała przeglądu definicji „przemysłów kultury”, „przemysłów kreatywnych” i „sektora kreatywnego” stosowanych przez organizacje międzynarodowe, raporty badawcze oraz różne kraje. W niniejszym artykule chodzi przede wszystkim o analizę relacji pojęcie-termin i na jej podstawie znalezienie możliwie najlepszych terminów polskich odnoszących się do pojęcia sektora kreatywnego. Dla uproszczenia przyjmijmy, że określenia wymienione wyżej („przemysły kreatywne”, „przemysły kultury” itd.) są różnymi terminami przyporządkowanymi temu samemu pojęciu - pojęciu sektora kreatywnego. Dla jasności argumentacji przyjmijmy również konwencję, że terminy będą ujęte w cudzysłów, a pojęcia nie.

\section{Geneza pojęcia sektora kreatywnego}

Pojęcie sektora kreatywnego ma dwa względnie niezależne źródła: (1) filozoficzne - związane z krytyką rodzącej się w pierwszej połowie XX w. kultury masowej, oraz (2) ekonomiczno-polityczne - związane $z$ ekonomizacją kultury w połowie $\mathrm{XX}$ w. oraz z polityką miejską, a następnie polityką gospodarczą ostatnich dekad XX w. Dlatego też w dalszej analizie wyróżnione zostaną dwa aspekty pojęcia sektora kreatywnego: filozoficzny i ekonomiczno-polityczny (ryc. 1). Celem poniższej charakterystyki jest pokazanie, że choć pojęcie sektora kreatywnego wywodzi się z filozoficznej refleksji nad kulturą, to współczesne pojęcie sektora kreatywnego ma przede wszystkim wymiar ekonomiczny i polityczny.

\section{Aspekt filozoficzny}

Kiedy w roku 1944 główni przedstawiciele tzw. szkoły frankfurckiej, Max Horkheimer i Theodor Adorno, po raz pierwszy użyli określenia „przemysł kulturalny” (niem. Kulturindustrie, ang. tłumaczenie jako culture industry), pojawił się termin, ale jeszcze nie pojęcie. Termin „przemysł kulturalny” stanowił dla tych autorów retoryczne narzędzie krytyki ideałów oświeceniowych oraz krytyki kapitalizmu formułowanej z perspektywy marksowskiej, co było zresztą główną osią teorii krytycznej rozwijanej przez szkołę frankfurcką. Źródła upadku tych ideałów szkoła dostrzegała już w samym oświeceniu, stąd rozdział w „Dialektyce oświecenia” poświęcony „przemysłowi kulturalnemu” nosi znamienny tytuł „Przemysł kulturalny. Oświecenie jako oszustwo mas" (Horkheimer, Adorno 1994). W rozdziale tym, podobnie jak i w wielu innych dziełach szkoły frankfurckiej, jest sporo - skądinąd trafnych - uwag o komercjalizacji sztuki w społeczeństwach uprzemysłowionych i o słabości produkcji artystycznej podporządkowanej żądaniom rynku. Zresztą Horkheimer i Adorno nie byli pierwszymi, którzy poruszali kwestie zmian dokonujących się w kulturze. Dla przykładu już wcześniej Walter Benjamin zwracał 
uwagę na standaryzację i masowość produkcji kulturowej w napisanym w 1936 r. eseju „Dzieło sztuki w dobie reprodukcji technicznej” (Benjamin 1975). Niemniej jednak, jak sam Adorno napisał blisko 20 lat później w artykule z 1963 r. „Résumé über Kulturindustrie” (ang. Culture industry reconsidered, „Refleksje na temat przemysłu kulturalnego”), termin „przemysł kulturalny” został użyty jako synonim kultury masowej (Adorno 2001, s. 98). Poprzez słowo „przemysł”, Horkheimer i Adorno nie odnosili się więc do samego procesu produkcji. Chcieli w ten sposób zwrócić uwagę na to, co dla ówczesnego przemysłu było charakterystyczne, czyli na standaryzację produktów, a także na racjonalizację technik dystrybucji. Chodziło im więc raczej o uprzemysłowienie w społecznym sensie, tj. wprowadzenie przemysłowych form organizacji do świata kultury i podporządkowanie jej funkcjonowania prawom rynkowym. Zatem termin „przemył kulturalny” u Horkheimera i Adorno: (1) pełnił rolę metafory retorycznej (por. Chojnicki 2003), używanej do krytyki kultury masowej i mającej wskazać na pewne analogie między działalnością przemysłową i kulturalną, (2) miał wyraźny negatywny ładunek aksjologiczny oraz (3) formułowany był z perspektywy kultury elitarnej, nazywanej

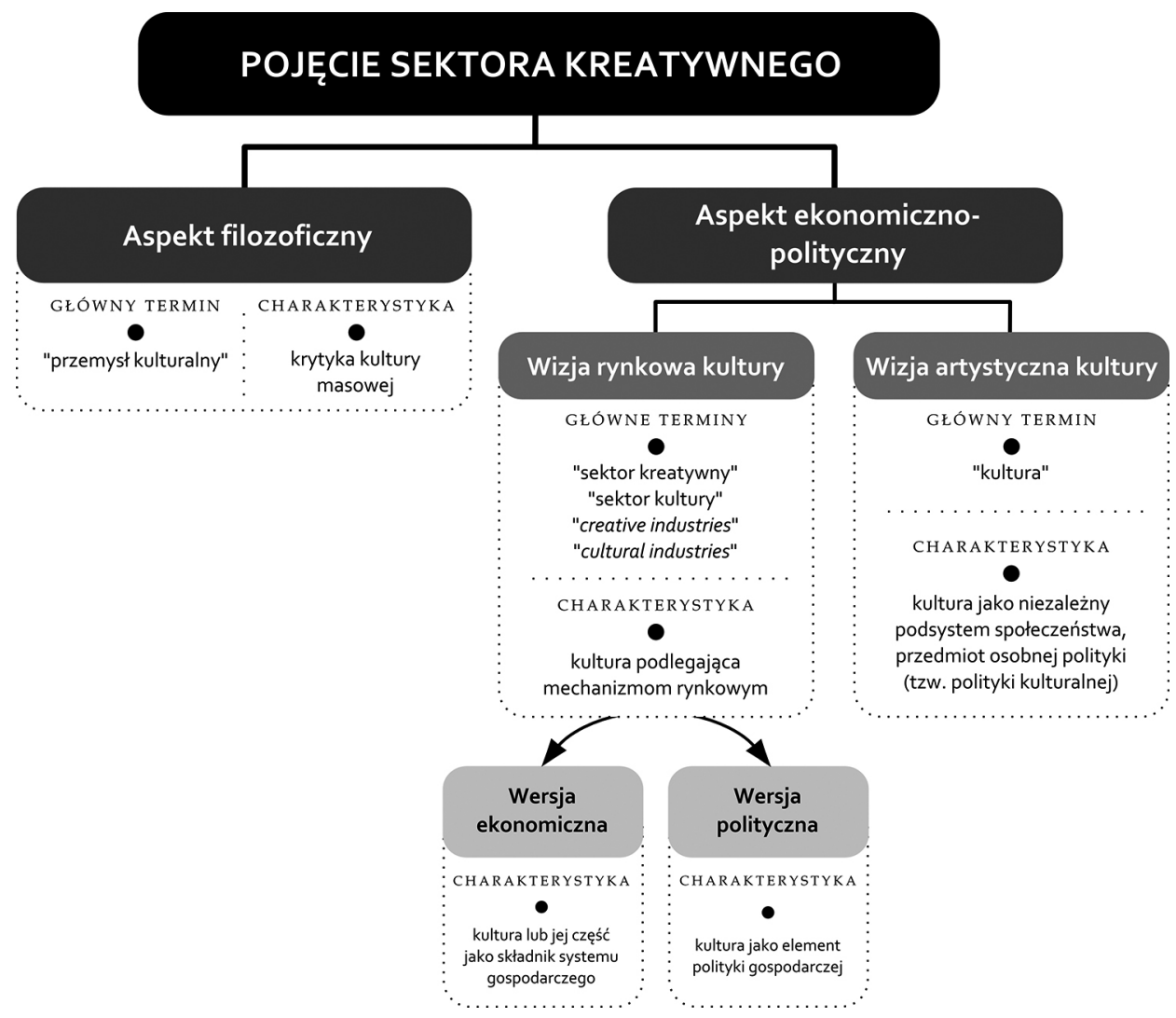

Ryc. 1. Geneza współczesnego pojęcia sektora kreatywnego

Źródło: opracowanie własne. 
też wysoką. Kołakowski (2009, s. 375-379) pisał następująco o podejściu szkoły frankfurckiej do kultury: „krytyka kultury, jakkolwiek zawiera rozmaite, od tego czasu już zbanalizowane, trafne uwagi na temat szkodliwych skutków komercjalizacji sztuki, podszyta jest najwyraźniej melancholijną tęsknotą za czasami, kiedy tylko elita uczestniczyła w odbiorze sztuki; jest to atak na «społeczeństwo masowe» w duchu feudalnej pogardy dla prostych ludzi. (...) Tak zwana kultura „wyższa" nie zginęła bynajmniej, stała się natomiast bez porównania łatwiej dostępna niż kiedykolwiek i z pewnością więcej ludzi z niej korzysta; twierdzenie zaś, że przewroty w formach tej sztuki w XX w. dadzą się wytłumaczyć ostatecznie panowaniem wartości wymiennej, jest nadzwyczaj nieprzekonujące".

Malinowski (1979, s. 176) zwraca uwagę, że sam Adorno w latach 60. XX w. dystansował się wobec swoich wcześniejszych prac, dostrzegając ich braki i uproszczenia (co ciekawe, dystansował się tylko wobec prac nie sygnowanych swoim prawdziwym nazwiskiem - jedna z takich prac z roku 1936 dotycząca krytyki muzyki jazzowej została napisana przez Adorno pod pseudonimem Hektor Rottweiler). Krytyka Horkheimera i Adorno była zresztą tylko jednym z kilku nurtów krytyki kultury masowej. Kłoskowska (1980/2005, s. 454) zwraca uwagę, że w szkole frankfurckiej krytyka ta przybierała postać fundamentalnej krytyki społecznej. Jej źródła były w dużej mierze wynikiem obserwacji i doświadczeń, jakie Horkheimer i Adorno zdobyli podczas emigracji do Stanów Zjednoczonych, która rozpoczęła się w latach 30. XX w. Kilkunastoletni pobyt w USA odcisnął wyraźne piętno na dalszych koncepcjach szkoły frankfurckiej na temat kultury i na sposobach jej analizy (Malinowski 1979, s. 175).

\section{Aspekt ekonomiczno-polityczny}

$\mathrm{Za}$ początki gospodarczego zainteresowania kulturą uznaje się pracę Baumola i Bowena (1966), która pierwsza w historii zawierała teoretyczną i empiryczną ekonomiczną analizę procesów kulturowych. Praca ta zainicjowała rozwój ekonomii kultury, najpierw stopniowo w Stanach Zjednoczonych, a później w Wielkiej Brytanii, Australii i Kanadzie i w szeregu innych krajów europejskich oraz azjatyckich, takich jak Japonia (Towse 2011 a, Ilczuk 2012). Blaug (2001), podsumowując historię kształtowania się ekonomicznej analizy kultury, wskazał na główne problemy, jakie były podejmowane przez ekonomię kultury. Były to m.in.: publiczne subsydiowanie kultury, rynek mediów, rynek sztuki, rynek pracy artystów, działanie organizacji non profit w kulturze, analiza popytu i podaży, kształtowanie preferencji konsumentów kultury. We wszystkich tych analizach rzadko stosowano termin cultural industries (chyba że w odniesieniu do prac Horkheimera i Adorno). Współczesny termin cultural industries używany jest co najmniej od lat 80. XX w. Z jednej strony termin ten służył międzynarodowym organizacjom, takim jak UNESCO, do zarysowania ich filozofii i polityki działania. Jednym $z$ celów tych organizacji było m.in. zwrócenie uwagi międzynarodowej społeczności na problem rozwoju kulturalnego i wprowadzenie go do głównego nurtu polityki (UNESCO 1982). Z drugiej używany był przez władze różnych miast, głównie w Wielkiej Brytanii, na oznaczenie działalności związanych z szeroko pojętą kulturą oraz procesów wytwarzania i rozpowszechniania dóbr kultury, które w pew- 
nych aspektach przypominały działania przedsiębiorstw na rynku (Garnham 1987). Cultural industries był więc konstruktem politycznym, którego celem była legitymizacja kultury w polityce publicznej, w szczególności w polityce gospodarczej. W pewnym momencie pojawił się nowy termin creative industries, również będący konstruktem politycznym, wprowadzonym w 1997 r. przez brytyjski rząd Partii Pracy, który przejął władzę w kraju po 18 latach rządzenia Partii Konserwatywnej. Pratt (2005, s. 32) podkreśla, że kiedy w Wielkiej Brytanii wprowadzono termin creative industries, zastępując dotychczasowy cultural industries, w zasadzie nie odbyła się żadna publiczna dyskusja na temat tego, dlaczego te terminy zmieniły się ani też jaka jest relacja nowego terminu do starego. Nowa nazwa miała być częścią nowego dyskursu politycznego i próbą zarysowania granicy między starą a nową polityką władz centralnych. Kilka lat wcześniej rząd australijski opublikował raport pt. „Creative nation” (1994) uważany za narodziny „przemysłów kreatywnych" (Howkins 2001). Pomimo, że bodaj po raz pierwszy użyto wtedy przymiotnika „kreatywny”, to dokument odnosił się do kultury i polityki kulturalnej. Podobnie w Wielkiej Brytanii zmiana $\mathrm{z}$ cultural na creative industries miała raczej charakter retoryczny - była to zmiana terminów, a nie pojęć. W konsekwencji wywarła jednak ogromny wpływ na interpretację pojęcia. Odtąd kulturę i działalności z nią powiązane zaczęto postrzegać przez pryzmat kreatywności, która stała się differentia specifica nowej nazwy i jej definicji. Dlatego też Galloway i Dunlop (2007) uważaja, że zmiana ta była czymś więcej niż tylko „zmianą marki”. Kultura i sztuka zostały odtąd włączone do sektora kreatywnego, co miało być oznaką przechodzenia do kształtującej się w latach 90. nowej „gospodarki wiedzy". Od tej pory pojęcie sektora kreatywnego nawiązywało zarówno do kultury, jak i do kreatywności, a także integrowało pewne gospodarcze aspekty działalności kulturalnej, takie jak komercjalizacja dóbr kultury.

Wspólną płaszczyzną obu zarysowanych wyżej aspektów pojęcia sektora kreatywnego - filozoficznego i ekonomiczno-politycznego - jest zjawisko postępującej ekonomizacji kultury. Według Kopeckiej-Piech (2013, s. 53) „ewidentny spór definicyjny o przemysły kreatywne toczy się między zwolennikami wizji ekonomicznej, rynkowej a zwolennikami wizji kulturowej, artystycznej". Ci pierwsi związani są z opcją neoliberalną, próbującą podporządkować mechanizmom rynkowym możliwie wiele dziedzin życia, a drudzy sprzeciwiają się ekonomizacji kultury. Spór ten ma w zasadzie charakter aksjologiczny oraz normatywny i dotyczy tego, jak powinniśmy traktować kulturę. Te dwie wizje wpływają jednak również na to, jak sektor kreatywny jest definiowany oraz na to, czy kultura jest jego częścią i jaka jest jego rola w społeczeństwie. Wizja artystyczna kultury nawiązuje do pierwotnych obaw Horkheimera i Adorno o to, że kultura i sztuka stały się nazbyt ustandaryzowane i „uekonomicznione”. W wielu krajach, np. we Francji, podejście „ekonocentryczne” do kultury jest dyskredytowane (Andres, Chapain 2012). Podobnie jest i w Polsce, o czym świadczy m.in. przeprowadzona w naszym kraju w 2012 r. kampania pt. „Teatr nie jest produktem, widz nie jest klientem”. $\mathrm{Z}$ kolei amerykańskie podejście nie upatruje $\mathrm{w}$ utowarowieniu kultury i sztuki nic nadzwyczajnego, bo w ten skomercjalizowany sposób tamtejsza kultura rozwijała się od jej początków (Martel 2008). W zasadzie podobne podejście jest 
w innych krajach anglosaskich, zwłaszcza w Wielkiej Brytanii i Australii. Debata „ekonocentryzm” kontra „kulturocentryzm” jest zresztą częścią szerszej dyskusji dotyczącej polityki kulturalnej i polityki publicznej oraz zarządzania w sektorze publicznym (zob. np. OECD 2007), a także ekonomizacji nierynkowych dziedzin życia (Polak, Polak 2013).

Wizja rynkowa kultury akcentuje zmieniającą się dynamikę relacji kultury i gospodarki. Smoleń (2003, s. 17-24) zwraca uwagę, że związki pomiędzy kulturą a gospodarką uległy istotnej zmianie - obie dziedziny coraz wyraźniej przenikają się i uzupełniają. Stąd też postrzeganie kultury jedynie w kategoriach sektora usług społecznych, które tylko generują koszty, a nie korzyści ekonomiczne, staje się nieadekwatne do obserwowanych zmian. Szomburg (2002) nazywa to „ekonomizacją” kultury i „kulturalizacją” gospodarki. Według niego „osobne myślenie o kulturze i ekonomii staje się anachronizmem we współczesnym świecie. (...) Coraz więcej wytworów gospodarczych - i w coraz większym stopniu - jest nasyconych inspiracjami i znaczeniami zakorzenionymi w kulturze, które podwyższają ich wartość, dając przewagę nad innymi wytworami. Z kolei sektor kultury i sztuki, zaliczany poprzednio do tak zwanej sfery usług społecznych (kreujących koszty, a nie korzyści ekonomiczne), coraz bardziej opuszcza tę sferę. Ulegając stopniowej komercjalizacji i «uprzemysłowieniu» produkcji, staje się samodzielną dziedziną gospodarowania, zwiększającą produkt krajowy brutto, tworzącą nowe, rentowne miejsca pracy. Siłą napędową tego procesu urynkowiania i umasowiania kultury stała się rewolucja informacyjno-telekomunikacyjna i nowe media, dzięki którym koszty procesów powielania i dystrybucji radykalnie się obniżyły. Między tymi dwiema sferami: artystycznej kreacji i ekonomicznej produkcji - traktowanymi dotychczas zupełnie odrębnie - trzeba zbudować nowe mosty, nowe, wzajemnie korzystne powiązania" (Szomburg 2002, s. 10).

\section{Kwestie polskich tłumaczeń terminów anglojęzycznych}

Polskojęzyczne terminy odnoszące się do sektora kreatywnego, takie jak „przemysły kreatywne” czy „przemysły kultury”, nie do końca odpowiadają pojęciom stojącym za nazwami obcojęzycznymi. Problem niedopasowania terminów do pojęć jest zresztą szerszy we współczesnej polskiej nauce. Łuczyński (2011, s. 131) tak charakteryzuje tę sytuację: „terminy angielskie coraz częściej wypierają swoje polskie odpowiedniki, a do języka naukowego wprowadzane są albo wprost słowa angielskie, albo ich spolszczone wersje. Wiele dziedzin nauki i techniki niemal całkowicie zrezygnowało z prób tworzenia własnej, polskiej, samodzielnej terminologii naukowej, w której wprowadzane pojęcia oparte są na polskim źródłosłowie. Efektem takiego stanu rzeczy jest z jednej strony zubożenie języka, a $z$ drugiej funkcjonowanie $w$ nim pojęć, które w polskim otoczeniu leksykalnym pozbawione są swoich wymiarów - semantycznego i etymologicznego". Opis ten pasuje również do sytuacji w badaniach sektora kreatywnego. Niech przykładem słabości polskich przekładów będzie tłumaczenie brytyjskiej definicji „creative industries", które opublikowane zostało w popularnym opracowaniu wykonanym na zlecenie Ministerstwa Gospodarki: „działalności, które mają swoje pochodzenie 
w indywidualnej kreatywności, umiejętności i talencie, mają potencjał do tworzenia bogactwa i kreacji pracy poprzez pokolenia i eksploracje intelektualnej własności” (Mackiewicz i in. 2009, s. 8). Oryginalna definicja brzmi: „those activities which have their origin in individual creativity, skill and talent and which have a potential for wealth and job creation through the generation and exploitation of intellectual property" (DCMS 1998, s. 3), co w wolnym tłumaczeniu oznacza działalności, które biorą się z indywidualnej kreatywności oraz talentu i które mają zarazem potencjał wytwarzania bogactwa oraz generowania nowych miejsc pracy dzięki wytwarzaniu i wykorzystywaniu własności intelektualnej.

Głównym źródłem problemu przekładu terminów creative industries lub cultural industries i innych wydaje się mechaniczny, bezrefleksyjny i dosłowny charakter tłumaczenia. A przecież istotą translatoryki jest tłumaczenie znaczeń wyrazów, z uwzględnieniem m.in. pragmatycznego kontekstu ich użycia, a nie dosłowne tłumaczenie samych wyrazów. Kielar (1988, s. 47) podsumowuje to następująco: „adekwatne tłumaczenie dosłowne jest raczej wyjątkiem niż regułą, o czym wie każdy doświadczony tłumacz. Z natury rzeczy teksty techniczne są bardziej podatne na tłumaczenie $\mathrm{w}$ jakimś stopniu dosłowne, ale nawet $\mathrm{w}$ ich przypadku efekt uzyskany tym sposobem jest niezadowalający, w szczególności z tego względu, że taki tekst przekładu zniekształca lub gubi sens albo nie odpowiada wymogom stylistycznym języka przekładu".

Termin industry ma w języku angielskim szersze znaczenie niż polski „przemysł" i odnosi się w zasadzie do wszystkich pozarolniczych działalności gospodarczych. Właściwie w każdym słowniku języka angielskiego można znaleźć podobną definicję (zob. np. Adam 1989). Goodall (1987, s. 234) pisze, że „w krajach anglojęzycznych termin ten jest używany zarówno w szerszym, jak i węższym sensie. W najszerszym znaczeniu industry odnosi się do jakiejkolwiek działalności gospodarczej (...). W węższym znaczeniu odnosi się do działalności fabryk, w których jedne dobra (surowce) są przetwarzane środkami mechanicznymi lub chemicznymi w bardziej wartościowe dobra". Stąd mówi się np. o insurance industry (działalność związana $\mathrm{z}$ ubezpieczeniami), tourism industry (działalność związana $z$ turystyka), a nawet service industry (usługi). Z punktu widzenia semantycznego pojęciu przemysłu w języku polskim bardziej odpowiada angielskie manufacturing.

Dlaczego więc creative industry tłumaczone jest jako „przemysł”? Czyżby W ostatnim czasie zmieniło się pojęcie związane z tym terminem? Otóż nic na to nie wskazuje. Pojęcie przemysłu w Polsce w zasadzie nie uległo zmianie w ciągu ostatnich kilkudziesięciu lat. Zarówno w słownikach językowych (np. „Wielki słownik języka polskiego”, „Słownik języka polskiego PWN”), jak i w zbiorach tekstów z różnych lat gromadzących informację na temat kontekstów użycia określonych słów (np. „Narodowy korpus języka polskiego”), a także w literaturze naukowej, pojęcie przemysłu obejmuje dział produkcji materialnej, w którym wydobywanie zasobów przyrody i przetwarzanie ich na środki produkcji oraz środki konsumpcji odbywa się na dużą skalę, na zasadzie podziału pracy i za pomocą maszyn (por. Fierla 1974, s. 9, Kortus 1986, s. 10-11, Janasz 1997, s. 42). Zmieniły się co najwyżej sposoby klasyfikacji lub operacjonalizacji przemysłu. Przykła- 
dowo w statystykach GUS-u przemysł nie jest osobną kategorią jak dawniej, ale grupą sekcji PKD, które obejmują: „Górnictwo i wydobywanie”, „Przetwórstwo przemysłowe”, „Wytwarzanie i zaopatrywanie w energię elektryczną, gaz, parę wodną, gorącą wodę i powietrze do układów klimatyzacyjnych” oraz „Dostawa wody; gospodarowanie ściekami i odpadami oraz działalność związana z rekultywacją" (GUS 2014).

Z powyższych względów używanie w języku polskim terminu „przemysł kreatywny” i przez analogię „przemysł kultury” nie znajduje uzasadnienia ani semantycznego, ani merytorycznego. Jeżeli bowiem przemysł rozumiany jest tak, jak wspomniano o tym wyżej, większość działalności zaliczonych do „przemysłów kreatywnych" nie pasuje do tej definicji. Owszem, można zauważyć, że produkcja niektórych dóbr kreatywnych ma w pewnym stopniu charakter przemysłowy. Przykładowo produkcja $\mathrm{w}$ branży filmowej lub muzycznej istotnie dokonuje się przy użyciu maszyn, podziale pracy i na dużą skalę. Te trzy cechy to jednak co najwyżej differentia specifica przemysłu, podczas gdy genus (dział produkcji materialnej, zajmujący się wydobywaniem zasobów przyrody i przetwarzaniem ich na środki produkcji oraz środki konsumpcji) jest zgoła inny. Pomimo że występują pewne analogie między działalnością przemysłową i niektórymi działalnościami kreatywnymi lub kulturowymi, nie uzasadnia to stosowania terminu "przemysł kreatywny” lub „przemysł kultury” w języku polskim. Używanie terminu „przemysł" ma zresztą dalsze konsekwencje semantyczne. Miejscem, w którym działa przemysł, jest zakład przemysłowy. Czy zatem muzeum, opera, firma architektoniczna lub agencja reklamowa są zakładami przemysłowymi?

\section{Propozycja terminologiczna}

Trudności związane $z$ ustaleniem zakresu pojęcia sektora kreatywnego i pojęć pokrewnych, np. sektora kultury, wynikają z szeregu czynników. Najważniejsze $z$ nich to:

- różnorodność rozumienia pojęcia kultury - niejednorodność pojmowania tego, czym jest kultura, jest wieloraka; Kroeber i in. (1952) zebrali i przeanalizowali ponad 160 definicji kultury i choć wiele $z$ nich ma pewne wspólne cechy, to wielość ujęć nie pozwala jednoznacznie określić, czym ona jest;

- różne wizje tego, jaką rolę kultura pełni w społeczeństwie - według Kopeckiej-Piech (2013) te wizje to z jednej strony wizja rynkowa, dostrzegająca i nawołująca do gospodarczego wykorzystania działalności kultury i jej wytworów, a z drugiej wizja artystyczna, sprzeciwiająca się ekonomizacji kultury (por. ryc. 1). W zależności od tego, która wizja jest danemu badaczowi bliższa, z takimi ujęciami sektora kreatywnego i kultury mamy do czynienia;

- różne wzorce badania sektora kultury - Throsby (2008) zwraca uwagę na to, że różne sposoby definiowania sektora kultury przyczyniły się do wytworzenia się odmiennych wzorców ich badania. W efekcie prowadzi to do różnych wyników, takich jak np. zróżnicowane szacunki ekonomiczne roli sektora kultury w gospodarce. Analiza Throsby'ego pokazuje, jak wiele rozbieżności klasyfikacyjnych występuje w głównych nurtach badań. Ich skutkiem są różne modele 
sektora kultury, a więc sposoby konceptualizacji tego, jak kultura funkcjonuje, czy jakie działalności są z nią związane. Wskazuje to przy tym na ogromną rolę definiowania i klasyfikowania w początkowych etapach badania nowego zjawiska - raz ugruntowane definicje rzutują bowiem na sposób rozumienia pojęć w długim okresie i na charakter uogólnień teoretycznych dokonywanych na ich podstawie. $\mathrm{Z}$ tego względu konieczność uporządkowania podstawowych pojęć ma decydujące znaczenie dla dalszych badań.

Wyżej wymienione czynniki sprawiają, że definicje sektora kreatywnego o budowie klasycznej, tj. poprzez podanie rodzaju (genus) i różnicy gatunkowej (differentia specifica), są kontestowane i dyskutowane, co prowadzi do szerokich „sporów o przemysły kreatywne" (Kopecka-Piech 2013). W związku z tym konstruuje się definicje o budowie nieklasycznej, które polegają na wskazaniu zakresów nazw, które w sumie dają zakres nazwy definiowanej (por. Ziembiński 2002, s. 48-52). Takie też podejścia można spotkać w głównych opracowaniach na temat sektora kreatywnego (np. DCMS 1998, KEA 2006, UNDP/UNCTAD 2008). Definicje takie enumeracyjnie wyliczają rodzaje działalności, które należą do sektora kreatywnego. Przykładem może być ujęcie przedstawione na rycinie 2, które nawiązuje do klasyfikacji zaproponowanej przez Komisję Europejską (KEA 2006). Oprócz wyliczenia działalności wchodzących w skład poszczególnych kategorii ujęcie to prezentuje również relacje zachodzące między pojęciami.

Tabela 2 zawiera propozycję terminologiczną, która przyjmuje za główne nazwy „branżę" i „sektor”. Branża ma już pewne ugruntowane tradycje w badaniach ekonomicznych i stanowi poziom mezoanalizy, czyli pomiędzy firmą a całą

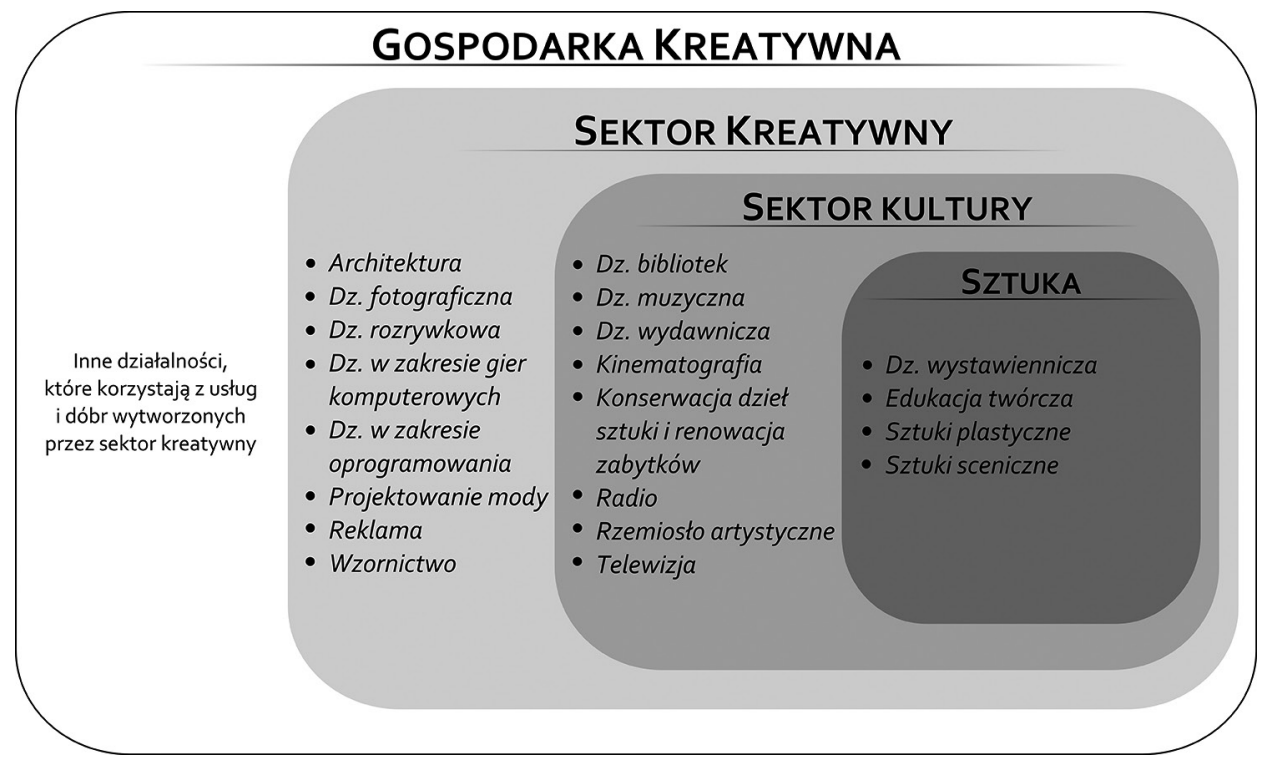

Ryc. 2. Przykładowa klasyfikacja i zależności między głównymi pojęciami związanymi z gospodarką kreatywną

Źródło: Tomczak, Stachowiak (2015, s. 9). 
Tabela 2. Głównie terminy związane z sektorem kreatywnym

\begin{tabular}{ll}
\hline \multicolumn{1}{c}{ Termin oryginalny (anglojęzyczny) } & \multicolumn{1}{c}{ Polski odpowiednik } \\
\hline Creative economy & Gospodarka kreatywna \\
Creative industries & Sektor kreatywny \\
& Działalności kreatywne \\
& Działalności twórcze \\
Cultural industries & Sektor kultury \\
& Działalności kulturalne \\
& Działalności związane z kulturą \\
Creative industry & Branża kreatywna \\
(w odniesieniu do całego zbioru podmiotów tej & np. branża filmowa, branża muzyczna lub \\
samej branży, np. film industry, music industry) & ewentualnie inne polskie odpowiedniki będące \\
& w powszechnym użyciu, takie jak kinematogra- \\
& fia, działalność muzyczna itd. \\
\hline
\end{tabular}

Pogrubioną czcionką zaznaczono główne terminy, natomiast normalną - terminy alternatywne. Źródło: opracowanie własne.

gospodarką (Gorynia i in. 2000). Grupa branż tworzy sektor, chociaż w literaturze ekonomicznej brak jest systematyki w tym zakresie. Niekiedy pojęcia sektora i branży są uznawane za synonimy, a czasami traktowane oddzielnie, wtedy rzadko dokonuje się jednoznacznego zdefiniowania różnic między nimi. Można przyjąć, że sektor jest pojęciem szerszym niż branża i obejmuje zintegrowany układ przedsiębiorstw, w którego skład wchodzą branże i podsektory (por. Pierścionek 2003). W takim ujęciu branża jest zatem zbiorem podmiotów lub działalności gospodarczych wytwarzających dobra lub usługi o podobnych cechach, a sektor jest zbiorem branż o podobnym charakterze. Branżą będzie więc np. kinematografia, działalność muzyczna architektura lub reklama, zaś sektor to zbiór tych branż wyróżniony w określony sposób (np. sektor kultury lub sektor kreatywny).

Zaletą terminu „sektor” jest to, że z jednej strony ma konotacje gospodarcze (sektor gospodarki), ale $\mathrm{z}$ drugiej te konotacje nie są tak silne jak w przypadku "przemysłu” (niemal odwrotnie jest w języku angielskim, w którym według Pratta (1997) „sector" ma silniejsze konotacje ekonomiczne niż „industry”). Throsby (2008) wskazuje zresztą na to, że gospodarcze traktowanie kultury nie powinno być interpretowane jako próba bezdusznej ekonomizacji kultury i zawłaszczenia jej przez nurty neoliberalne. Chodzi raczej o stworzenie możliwości legitymizacji polityki kulturalnej w polityce publicznej, która na różnych szczeblach - od lokalnego do międzynarodowego - jest współcześnie zdominowana przez dyskurs gospodarczy. „W ten sposób kultura uzyskuje swoje miejsce przy stole, którego w innej sytuacji mogłaby nie otrzymać" (Throsby 2008, s. 230).

Szerszym i jednocześnie nadrzędnym pojęciem w stosunku do sektora kreatywnego jest pojęcie gospodarki kreatywnej (por. ryc. 2). Odpowiada to obecnemu $\mathrm{w}$ ostatnich latach $\mathrm{w}$ literaturze ponadsektorowemu spojrzeniu, które obejmuje nie tylko funkcjonowanie samego sektora kreatywnego, ale także wykorzystanie usług i dóbr kreatywnych w innych częściach gospodarki (Higgs i in. 2008, Cunningham 2011, Bakhshi i in. 2013). Podobnie Pratt (2008a, c) sugeruje badanie branż kreatywnych szerzej niż do tej pory, tj. z perspektywy łańcucha 
wartości dodanej, który obejmuje nie tylko proces wytwarzania dóbr kreatywnych, ale również ich dystrybucję i konsumpcję. Dzięki takiemu podejściu otrzymujemy głębszy obraz powiązań sektora kreatywnego z resztą gospodarki, przez co jesteśmy w stanie pełniej ocenić jego gospodarczą rolę.

\section{Przedmiot badań}

Sektor kreatywny stał się w ostatnich 20 latach odrębnym przedmiotem badań różnych dyscyplin nauk społecznych. Jednak badania te prowadzone są na różnych poziomach analizy, a przez to odnoszą się do innych aspektów sektora kreatywnego. W tradycyjnej analizie ekonomicznej wyróżnia się dwa poziomy analizy: makro, który bada gospodarkę jako całość, i mikro, gdzie przedmiotem badań są zachowania gospodarstw domowych, przedsiębiorstw i rynków, na których obie kategorie podmiotów działają. Gorynia (1993, s. 505) zwraca uwagę, że to tradycyjne ujęcie poziomów analizy przestało wystarczać, dlatego $\mathrm{w}$ drugiej połowie XX w. wyłoniły się trzy kolejne poziomy analizy: mikromikro, mezo i globalny. Pierwszy odnosi się do jednostki ludzkiej, drugi do poziomu branży, a trzeci to poziom gospodarki światowej. Nawiązując do tej klasyfikacji, wyróżniono następujące poziomy analizy w badaniach sektora kreatywnego, stanowiących jednocześnie ich odniesienie przedmiotowe:

- Jednostka - na tym poziomie badania skupiają się na człowieku i jego kreatywności. Ta perspektywa dotyczy z jednej strony roli jednostek w sektorze kreatywnym, czego przykładem są badania dotyczące charakteru i specyfiki pracy w sektorze kreatywnym i szerzej pracowników firm sektora kreatywnego (Hesmondhalgh, Baker 2011) oraz ich cech, takich jak np. przedsiębiorczość (Henry 2007). Z drugiej strony badania na tym poziomie odnoszą się do jednostek zagregowanych lub zorganizowanych $\mathrm{w}$ większe struktury, takie jak np. grupy artystów (Markusen, Schrock 2006) czy tzw. klasa kreatywna (Florida 2002).

- Firma - poziom ten odpowiada ekonomicznemu poziomowi mikro. Badania dotyczą specyfiki funkcjonowania firm lub innych podmiotów sektora kreatywnego, ich efektywności, wytwarzanych dóbr oraz popytu na nie, analizy kosztów itd. (Caves 2000). Badań na poziomie mikro jest relatywnie niewiele, a dobrym przykładem tego typu studiów są mikroekonomiczne analizy funkcjonowania teatrów (Garboua, Montmarquette 1996, Trzeciak 2011).

- Branża lub zbiór branż - na tym poziomie badania dotyczą pojedynczej branży, np. branży filmowej (Scott 2004), muzycznej (Lange, Bürkner 2013) czy gier wideo (Plum, Hassink 2014), grupy branż (np. branże audiowizualne) lub całego sektora kreatywnego (Flew 2012).

- Miasto lub region - ten poziom analizy jest swego rodzaju syntetycznym połączeniem innych poziomów, tj. jednostkowego, firmowego lub branżowego, $z$ tym, że analiza ograniczona jest przestrzennie do określonej jednostki przestrzennej, którą najczęściej jest miasto lub region. Ten nurt badań sektora kreatywnego jest na tyle rozwinięty, że wykształcił się jako osobny przedmiot 
badań, wraz ze swoimi oryginalnymi teoriami, takimi jak koncepcja miasta kreatywnego (Landry, Bianchini 1995, Landry 2000) czy kreatywnego regionu (Cooke, Schwartz 2007, Chapain i in. 2013).

- Gospodarka - poziom ten nawiązuje do poziomu makro w badaniach ekonomicznych i odnosi się z jednej strony do badań sektora kreatywnego w odniesieniu do całej gospodarki, zarówno w skali krajowej (Fesel, Söndermann 2007), jak i globalnej (UNDP, UNESCO 2013), z drugiej strony obejmuje badania roli sektora kreatywnego w całej gospodarce i akcentuje jego wpływ na inne sektory gospodarki (Bakhshi i in. 2013).

Należy zwrócić uwagę, że poziomy analizy wpływają często na metodologiczny charakter koncepcji teoretycznej, a przez to na sposób badania sektora kreatywnego. Skrajne poziomy analizy (jednostki i gospodarki) odpowiadają stanowiskom indywidualizmu i holizmu metodologicznego (por. Bunge 2000). Koncepcja klasy kreatywnej Floridy (2002) ma charakter indywidualistyczny, a koncepcje na kolejnych poziomach, takie jak koncepcja gospodarki kreatywnej (Bakhshi i in. 2013) czy kapitalizmu kognitywno-kulturowego (Scott 2008), przesuwają się do ujęć bardziej holistycznych.

Wyróżnione wyżej przedmioty badań i poziomy analizy odniesiono do grupy 209 prac na temat sektora kreatywnego, które poddano analizie pod kątem problemów metodologicznych. Okazało się, że głównym przedmiotem badań sektora kreatywnego jest branża - stanowiła ona centralny przedmiot zainteresowania ponad połowy analizowanych prac (tab. 3). Badania na poziomie jednostki oraz miasta są również ważnymi nurtami. Natomiast wyraźnie zaznacza się niedostatek badań na poziomie mikro. Zauważa to też Spencer (2012, s. 267), który twierdzi, że sektor kreatywny doczekał się ogromnej ilości studiów, zwłaszcza ekonomicznych i geograficznych, jednak mało kto próbuje analizować mikropodstawy procesów twórczych i działalności podmiotów sektora kreatywnego. Zamiast tego badacze koncentrują się na kontekstach przestrzennych, w jakich procesy kreatywne zachodzą.

Sprawę przedmiotu badań komplikuje fakt, że wiele studiów nad sektorem kreatywnym przeprowadzanych jest w różnych skalach przestrzennych. Spośród

Tabela 3. Główny przedmiot badań i poziomy analizy prac na temat sektora kreatywnego

\begin{tabular}{lrr}
\hline $\begin{array}{c}\text { Główny przedmiot } \\
\text { badań } \\
\text { (poziom analizy) }\end{array}$ & $\begin{array}{c}\text { Liczba } \\
\text { prac }\end{array}$ & \multicolumn{1}{c}{$\%$} \\
\hline Jednostka & 36 & 17,2 \\
Firma & 2 & 1,0 \\
Branża & 115 & 55,0 \\
Miasto & 44 & 21,1 \\
Gospodarka & 12 & 5,7 \\
\hline Razem & 209 & 100,0 \\
\hline
\end{tabular}

Źródło: opracowanie własne. 209 przebadanych prac tylko niespełna $4 \%$ nie miało odniesienia przestrzennego (tab. 4). Ten sam przedmiot może być zatem badany $\mathrm{w}$ różnych skalach przestrzennych, np. analiza branży w jednym przypadku ograniczy się do miasta, a w innym będzie dotyczyła całego kraju. To utrudnia wykrywanie prawidłowości i formułowanie generalizacji empirycznych odnoszących się do całego sektora kreatywnego. Z tabeli 4 wynika, że większość $(38,3 \%)$ badań sektora kreatywne- 
Tabela 4. Skala przestrzenna badań sektora kreatywnego

\begin{tabular}{lcc}
\hline \multicolumn{1}{c}{ Skala przestrzenna badania } & Liczba prac & $\%$ \\
\hline Miejsce (skala sublokalna) & 4 & 1,9 \\
Miasto & 36 & 17,2 \\
Aglomeracja lub obszar metropolitalny & 20 & 9,5 \\
Region & 20 & 9,6 \\
Kraj & 74 & 35,4 \\
Kontynent & 27 & 12,9 \\
Skala globalna & 20 & 9,6 \\
Brak określonej skali przestrzennej & 8 & 3,8 \\
\hline Razem & 209 & 100,0
\end{tabular}

Źródło: opracowanie własne.

go wykonywanych jest w skali regionalnej i lokalnej, choć duże znaczenie ma również skala krajowa.

\section{Rodzaj i źródła danych}

Jak zaznaczono wyżej, przedmiot badań w analizach sektora kreatywnego jest niejednorodny - od jednostki, przez firmę i branżę, po gospodarkę. To pociąga za sobą zróżnicowanie wykorzystywanych danych, dlatego też zbadano rodzaj i źródła danych, jakie pojawiają się w pracach na temat sektora kreatywnego. Trzeba tu zaznaczyć, że te dwie kategorie - rodzaj i źródła danych - nie są zupełnie rozłączne, stąd mogą pojawić się pewne trudności interpretacyjne, jednak chciano w ten sposób sprawdzić zarówno specyfikę stosowanych danych, jak i ich pochodzenie. Te dwie kategorie mają charakter komplementarny i należy je traktować jak dwa różne sposoby patrzenia na ten sam problem, jakim jest wykorzystanie danych empirycznych w badaniach sektora kreatywnego.

Przyjęto, że dane mogą mieć charakter pierwotny albo wtórny. Przez dane pierwotne rozumiano oryginalne informacje pozyskane w ściśle określonym celu - w tym przypadku zgromadzone dla celów badawczych. Do danych o charakterze pierwotnym zaliczono wyniki badań własnych autorów, tj. wyniki badań terenowych, ankiet, wywiadów, obserwacji, bazy danych opracowane na potrzeby danego badania, a także teksty źródłowe, takie jak dokumenty urzędowe, relacje świadków, teksty ustaw, pamiętniki, reportaże, materiały prasowe, dokumentacja techniczna itp. Przez dane wtórne rozumiano informacje, które już istniały w momencie przeprowadzania badania lub zostały zebrane i opracowane przez inne podmioty, w innym celu niż dane badanie. Do wtórnych danych zaliczyć można informacje pozyskiwane ze źródeł już istniejących, takich jak np. urzędy statystyczne, bazy danych opracowane przez inne podmioty, wyniki badań innych autorów - dzięki temu pozyskanie takich danych nie wymaga prowadzenia bezpośrednich badań. Dane statystyczne zaliczono do wtórnych źródeł danych, chyba że zostały wytworzone przez autora na potrzeby przeprowadzonego przez 
Tabela 5. Główny rodzaj danych używanych w pracach dotyczących sektora kreatywnego

\begin{tabular}{lcc}
\hline Główny rodzaj danych & Liczba prac & $\%$ \\
\hline Pierwotne & 41 & 19,6 \\
Wtórne & 143 & 68,4 \\
Pierwotne i wtórne & 25 & 12,0 \\
\hline Razem & 209 & 100,0 \\
\hline
\end{tabular}

Źródło: opracowanie własne. niego badania. Artykuł lub opracowanie zakwalifikowano do danej grupy, jeżeli główne dane użyte w takiej pracy, na których podstawie przeprowadzano analizy i wyciągano wnioski, miały charakter pierwotny lub wtórny. Wyniki tej klasyfikacji przestawiono $\mathrm{w}$ tabeli 5. Pokazuje ona, że dane wtórne, przede wszystkim o charakterze statystycznym, dostarczane zarówno przez urzędy statystyczne, jak i różnego rodzaju organizacje, stanowiły trzon informacji o sektorze kreatywnym.

Uzupełnieniem informacji o rodzaju danych wykorzystywanych w badaniach sektora kreatywnego jest identyfikacja źródeł danych. Dla przejrzystości analizy starano się ustalić podstawowe źródła danych, tj. takie, z których pochodziła większość informacji użytych w danej pracy lub na podstawie których opierano dane badanie. W wielu przypadkach występowały dwa lub więcej głównych źródeł danych, stąd wartości procentowe w ostatniej kolumnie tabeli 6 nie sumują się do 100. Wydzielono 6 kategorii źródeł danych:

- urzędy statystyczne - zaliczono do nich urzędy statystyczne różnych szczebli i krajów, a także spisy powszechne i rejestry (np. rejestr podmiotów gospodarczych);

- badania własne - ta kategoria odnosiła się do sytuacji, w której dane zostały zebrane w wyniku własnych badań autora publikacji;

- organizacje pozarządowe - zaliczono do nich wszelkie organizacje branżowe (np. Polski Instytut Sztuki Filmowej, British Film Council, British Phonographic Industry), a także organizacje krajowe i międzynarodowe (Nesta, OECD, WIPO, Bank Światowy, UNESCO itd.);

- władza publiczna - stanowiły ją wszelkie organy władzy publicznej, takie jak ministerstwa, urzędy centralne, regionalne i lokalne, samorządy, agencje rozwoju lokalnego i regionalnego, Komisja Europejska; podstawowymi rodzajami danych udostępnianych przez te źródła były dokumenty, raporty lub strategie, a rzadziej bazy danych;

Tabela 6. Główne źródła danych używanych w pracach dotyczących sektora kreatywnego

\begin{tabular}{lccc}
\hline \multicolumn{1}{c}{ Główne źródło danych } & Liczba wystąpień & \% wystąpień & \% wszystkich prac (N=209) \\
\hline Urząd statystyczny & 140 & 46,4 & 67,0 \\
Badania własne & 70 & 23,2 & 33,5 \\
Organizacja pozarządowa & 39 & 12,9 & 18,7 \\
Władza publiczna & 24 & 7,9 & 11,5 \\
Literatura & 15 & 5,0 & 7,2 \\
Internet & 14 & 4,6 & 6,7 \\
\hline Razem & 302 & 100,0 & - \\
\hline
\end{tabular}

Źródło: opracowanie własne. 
- literatura - do tej kategorii zaliczono przypadki, w których w badanych pracach wykorzystano dane zebrane przez innych autorów;

- Internet - za źródła internetowe uznano te zbiory informacji, które są dostępne tylko za pośrednictwem Internetu; stanowiły je przede wszystkim strony internetowe, czasopisma internetowe lub internetowe bazy danych, takie jak Google Scholar czy Internet Movie Database, będące niezależnymi przedsięwzięciami różnych firm lub grup prywatnych ludzi; nie wliczano do tych źródeł baz danych udostępnianych przez urzędy statystyczne (np. Bank Danych Lokalnych GUS, Eurostat), organy władzy publicznej ani inne organizacje wymienione wyżej.

Wyniki analizy przedstawiono w tabeli 6 . Jak widać, najczęstszym źródłem danych są urzędy statystyczne, które były wykorzystywane w $2 / 3$ wszystkich badanych prac. Nie mniej istotne są badania własne autorów, które pozwalają zgromadzić nowe dane na temat sektora kreatywnego i które same stają się źródłem danych dla innych prac.

\section{Metody badań}

Jedną z głównych cech badań sektora kreatywnego jest pluralizm metodologiczny, który - najkrócej rzecz ujmując - charakteryzuje się stosowaniem wielu różnych metod przy opisie i wyjaśnianiu zjawisk. Podejście pluralistyczne obecne jest $w$ wielu naukach społecznych, np. w socjologii (Payne i in. 2004), ekonomii (Salanti, Screpanti 1997) czy geografii społeczno-ekonomicznej (Barnes, Sheppard 2010), a współczesne studia metodologiczne nazywają je „metodologią mieszaną" (Brannen 2005, Yeager, Steiger 2013, Starr 2014). Owo mieszanie polega przede wszystkim na stosowaniu podejść ilościowych i jakościowych w badaniu tych samych zjawisk. Trudność tkwi jednak w precyzyjniejszym określeniu, czym są obie te kategorie i gdzie jest granica między nimi. Chojnicki (2010, s. 94-95) zwraca uwagę, że „samo pojęcie podejścia jakościowego nie jest też jednoznaczne i trudno je wyraźnie określić, ze względu chociażby na nieostrość kategorii ilości i jakości w odniesieniu do skal pomiaru, jak też analitycznych instrumentów pojęciowych. W związku z tym niewłaściwe jest przedstawianie podejścia jakościowego jako pola badań, w którym stosuje się aparat pojęciowy nie zawierający miar liczbowych (wielkości)". Według Nowaka (1985, s. 153) z kategorią jakościową mamy do czynienia wtedy, gdy pytanie o intensywność danej cechy nie jest sensowne. Oba ujęcia - jakościowe i ilościowe - stanowią integralne, a zarazem komplementarne podejścia w badaniach (Sechrest, Sidani 1995). Prace badawcze uważane za jakościowe zwykle zawierają także elementy ilościowe, chociażby w formie informacji ilościowych.

Tabela 7. Główne rodzaje metod stosowanych $\mathrm{w}$ badaniach sektora kreatywnego

\begin{tabular}{lcr}
\hline Rodzaj metod & Liczba prac & $\%$ \\
\hline Ilościowe & 111 & 53,1 \\
Jakościowe & 88 & 42,1 \\
Mieszane & 20 & 9,6 \\
\hline Razem & 209 & 100,0 \\
\hline
\end{tabular}

Źródło: opracowanie własne. 
Podejście pluralistyczne, rozumiane jako jednoczesne stosowanie metod ilościowych i jakościowych, w pojedynczych badaniach sektora kreatywnego stosowane jest względnie rzadko. Najczęściej pojawia się ono w dużych pracach, takich jak np. opracowania książkowe lub obszerne raporty diagnostyczne. Z badanych 209 prac niespełna w 10\% stosowano zarówno metody ilościowe, jak i jakościowe (tab. 7). Autorzy badań decydowali się najczęściej na wybór jednej z grup metod i w efekcie $53 \%$ z nich wybierało metody ilościowe, a $42 \%$ metody jakościowe. Pluralizm metodologiczny odnosi się więc do całej dziedziny badań, a nie do pojedynczych prac. W rezultacie wiedza wytworzona przez te badania ma różnorodny charakter. Jak wiadomo, stosowanie różnych metod wymaga formułowania odmiennych założeń lub odwoływania się do różnych teorii. To w połączeniu z różnym statusem ontologicznym i epistemologicznym przedmiotu badań, który, jak wykazano wcześniej, też jest mocno zróżnicowany, powoduje, że wiedza o sektorze kreatywnym ma eklektyczny charakter. Zaletą podejścia pluralistycznego jest to, że obraz sektora kreatywnego, jaki w jego wyniku otrzymujemy, jest pełniejszy - metody ilościowe pozwalają uchwycić te aspekty, których nie wychwycą metody jakościowe - i odwrotnie.

W tabeli 8 przedstawiono główne metody ilościowe i jakościowe stosowane w badaniach sektora kreatywnego. W wielu pracach wykorzystano więcej niż jedną metodę, stąd obliczono liczbę wystąpień danej grupy metod w badanym zbiorze opracowań. Do najczęstszych metod należał opis statystyczny, który był użyty w ponad 2/5 prac. Niemal równie często wykorzystywano jakościową analizę tekstów i metodę wywiadu. Ta ostatnia służyła na ogół zbieraniu nowych infor-

Tabela 8. Najczęściej stosowane metody w badaniach sektora kreatywnego

\begin{tabular}{|c|c|c|c|}
\hline \multicolumn{4}{|c|}{ Metody ilościowe } \\
\hline Metoda & $\begin{array}{c}\text { Liczba } \\
\text { wystąpień }\end{array}$ & $\begin{array}{c}\% \\
\text { wystąpień }\end{array}$ & $\begin{array}{l}\% \text { wszystkich prac } \\
(\mathrm{N}=209)\end{array}$ \\
\hline Opis statystyczny & 73 & 40,8 & 34,9 \\
\hline Analiza korelacji & 22 & 12,3 & 10,5 \\
\hline Ankieta & 20 & 13,6 & 9,6 \\
\hline Metody analizy lokalizacyjnej & 19 & 10,6 & 9,1 \\
\hline Analiza regresji & 16 & 8,9 & 7,7 \\
\hline Model ekonometryczny & 12 & 6,7 & 5,7 \\
\hline Inne metody ilościowe & 17 & 9,5 & 8,1 \\
\hline Razem & 179 & 100,0 & - \\
\hline \multicolumn{4}{|c|}{ Metody jakościowe } \\
\hline Metoda & $\begin{array}{c}\text { Liczba } \\
\text { wystąpień }\end{array}$ & $\begin{array}{c}\% \\
\text { wystąpień }\end{array}$ & $\begin{array}{c}\% \text { wszystkich prac } \\
(\mathrm{N}=209)\end{array}$ \\
\hline Analiza tekstów (literatury, dokumentów) & 61 & 41,5 & 29,2 \\
\hline Wywiad & 61 & 41,5 & 29,2 \\
\hline Analiza studiów przypadków & 8 & 5,4 & 3,8 \\
\hline Obserwacja uczestnicząca & 5 & 3,4 & 2,4 \\
\hline Inne metody jakościowe & 12 & 8,2 & 5,7 \\
\hline Razem & 147 & 100,0 & 70,3 \\
\hline
\end{tabular}

Źródło: opracowanie własne. 
macji o sektorze kreatywnym, podczas gdy dwie pozostałe operowały zwłaszcza danymi wtórnymi. Trzeba dodać, że analiza tekstu dotyczyła zarówno studiów literaturowych, jak i analizy tekstów źródłowych, przede wszystkim dokumentów strategicznych i politycznych. Z metod ilościowych stosowano również nierzadko metody analizy przestrzennej, takie jak autokorelacja przestrzenna, statystki najbliższego sąsiedztwa, metody analizy koncentracji przestrzennej (iloraz lokalizacji, krzywa Lorenza). Za ich pomocą pokazywano rozmieszczenie zjawisk lub też identyfikowano przestrzenne formy organizacji (tzw. klastry kreatywne). Wizualizacje kartograficzne, które cechują się dużą zawartością informacyjną, przedstawiające np. rozmieszczenie podmiotów sektora kreatywnego, należały do rzadkości. Nie brakowało klasycznej analizy statystycznej oraz modelowania ekonometrycznego, które łącznie pojawiły się w 22,5\% prac.

Ze względu na to, że opis statystyczny był najczęściej stosowaną metodą charakterystyki sektora kreatywnego, rozszerzono analizę i zbadano głębiej, jakie wskaźniki używane były do takiego opisu. Wskaźnik, w znaczeniu metodologicznym, stanowi pewną własność (cechę) obserwacyjną, która konkretyzuje i nadaje charakter empiryczny pewnej własności (cesze) nieobserwacyjnej (por. Nowak 1985, s. 165 i nast.). Wyróżniono 6 grup wskaźników, które używane są w badaniach sektora kreatywnego:

- zatrudnienie - to wszystkie wskaźniki związane z rynkiem pracy w sektorze kreatywnym, które najczęściej odnosiły się do liczby zatrudnionych w tym sektorze (przedstawiane w ujęciu bezwzględnym i względnym);

- liczba podmiotów - to wszystkie wskaźniki będące wynikiem zliczania podmiotów sektora kreatywnego, przede wszystkim liczba podmiotów gospodarczych, ale także podmiotów innego rodzaju, takich jak liczba instytucji kultury, liczba organizacji non profit itp.; wskaźniki te przedstawione były zarówno w ujęciu bezwzględnym, jak i względnym;

- wartość ekonomiczna - to grupa wskaźników przedstawiająca ekonomiczny aspekt danego zjawiska w ujęciu wartościowym, np. cena, przychody, wpływy, wydatki (np. na kulturę), import, eksport itp.; do tej grupy zaliczają się także wskaźniki wartości dodanej (np. wartość dodana brutto, produkt krajowy brutto);

- lokalizacja - to grupa wskaźników odnoszących się do lokalizacyjnych lub przestrzennych aspektów sektora kreatywnego, czego przykładem mogą być iloraz lokalizacji lub gęstość na jednostkę powierzchni;

- pozostałe wskaźniki ilościowe - to inne niż wyżej wymienione, ale związane bezpośrednio z sektorem kreatywnym zmienne ilościowe używane w badanej pracy, np. liczba imprez kulturalnych, liczba filmów, liczba miejsc spotkań artystów itp.;

- inne wskaźniki to takie, które nie są związane bezpośrednio z sektorem kreatywnym, ale służyły w jakiś sposób do badania, najczęściej w charakterze zmiennych niezależnych, np. liczba mieszkańców, ceny nieruchomości, liczba patentów itp.

W zdecydowanej większości badanych prac $(86,6 \%)$ pojawiał się co najmniej jeden wskaźnik - przede wszystkim o charakterze ilościowym - za którego pomo- 
Tabela 9. Wskaźniki używane w pracach dotyczących sektora kreatywnego

\begin{tabular}{lccc}
\hline \multicolumn{1}{c}{ Grupa wskaźników } & $\begin{array}{c}\text { Liczba } \\
\text { wystąpień }\end{array}$ & $\begin{array}{c}\text { \% sumy } \\
\text { wszystkich } \\
\text { wystąpień }\end{array}$ & $\begin{array}{c}\text { \% prac stosujących wskaźniki } \\
(\mathrm{N}=181), \text { w których pojawia się } \\
\text { wskaźnik z danej grupy }\end{array}$ \\
\hline Zatrudnienie & 114 & 26,8 & 63,0 \\
Wartość ekonomiczna & 95 & 22,3 & 54,4 \\
$\quad$ w tym wartość dodana & 35 & 8,2 & 19,3 \\
Liczba podmiotów & 81 & 19,0 & 44,8 \\
Lokalizacja & 7 & 1,6 & 3,9 \\
Pozostałe wskaźniki ilościowe & 77 & 18,1 & 42,5 \\
Inne wskaźniki & 24 & 5,6 & 13,3 \\
\hline Razem & 426 & 100,0 & \\
\hline
\end{tabular}

Źródło: opracowanie własne.

cą badano empirycznie sektor kreatywny. Łącznie w 181 pracach zidentyfikowano 426 różnych wskaźników, które przyporządkowano do jednej z wyżej wymienionych kategorii. Średnio w jednej pracy użyto 2,4 wskaźnika. Najczęściej stosowanymi wskaźnikami, za których pomocą bada się sektor kreatywny są, wskaźniki związane z zatrudnieniem oraz wartością ekonomiczną, a także z liczbą podmiotów (tab. 9). Te trzy grupy stanowią 2/3 wszystkich wystąpień wskaźników. Niemal w każdej pracy stosuje się któryś z tych trzech rodzajów wskaźników. Stanowią one dość powszechnie przyjęty sposób badania rozmiaru i znaczenia sektora kreatywnego w gospodarce. Bardzo często, bo w 42,5\% wszystkich prac, w których wykorzystano wskaźniki, autorzy proponowali swoje sposoby konkretyzacji empirycznej badanych zjawisk. Do ciekawszych i bardziej charakterystycznych można zaliczyć: liczba instruktorów flamenco na mieszkańca, udział nielegalnych kopii w sprzedaży muzyki i filmów, liczba widzów i słuchaczy w teatrach i instytucjach muzycznych, odsetek przedstawicieli tzw. bohemy, liczba muzyków i ich procentowe zmiany, liczba imprez w sektorze kultury, liczba sprzedanych albumów muzycznych, liczba sprzedanych biletów (na seanse kinowe, koncerty itd.).

\section{Charakter wiedzy o sektorze kreatywnym}

Wiedzę naukową danej dyscypliny stanowią uporządkowane oraz intersubiektywnie kontrolowalne i komunikowalne systemy twierdzeń odnoszących się do dziedziny tej nauki i mieszczących się w jej polu problemowym. Rozpatrując wiedzę o sektorze kreatywnym, trzeba zwrócić uwagę na co najmniej trzy jej aspekty: 1) kwestię relacji wiedza potoczna a naukowa, 2) charakter funkcjonalny wiedzy, 3) multidyscyplinarny charakter wiedzy.

Ad 1. Obok wiedzy naukowej wyróżnia się wiedzę potoczną, którą w porównaniu z wiedzą naukową cechuje niski poziom ogólności, ścisłości i stosowalności oraz mała zawartość informacyjna, a jej wytwarzanie nie poddaje się rygorom metodologicznym nauk empirycznych (por. Such, Szcześniak 1997, s. 35-41). Wiedza potoczna stanowi otoczenie wiedzy naukowej i te dwa rodzaje wiedzy nie powinny być przeciwstawiane. Niektóre nauki zawierają jednak wiedzę potoczną. 
Zaliczyć do nich należy pewną część wiedzy społecznej, a zwłaszcza historycznej, politologicznej, wiedzy o kulturze. Wydaje się, że w tej sytuacji jest dość spora część wiedzy o sektorze kreatywnym, w której przypadku empiryczna wiedza naukowa zazębia się z wiedzą potoczną. Dotyczy to zwłaszcza wiedzy czysto informacyjnej, którą uzyskuje się z różnych źródeł statystycznych, a także z opisu licznych studiów przypadków. Zasadniczą słabością tego rodzaju wiedzy jest to, że jej opracowanie nie wymaga szczególnych kompetencji badawczych, a więc nie ma charakteru specjalistycznego, chociaż czasem udaje, że ma taki charakter.

Ad 2. Charakterystyka metodologiczna wiedzy naukowej jest zwykle rozpatrywana w trzech aspektach: 1) strukturalnym - jak wiedza jest zbudowana, 2) funkcjonalnym - czemu służy, 3) ekonomicznym - do kogo należy. W odniesieniu do wiedzy o sektorze kreatywnym przyjęto charakterystykę mieszaną, ale za jej podstawę uznano kryterium funkcji, jakie pełni wiedza $\mathrm{w}$ procesie poznawania i przekształcania świata. Pozwala to wyróżnić: a) wiedzę informacyjno-opisową, która ma charakter opisowy i publiczny, b) wiedzę eksplanacyjno-prognostyczną, która ma charakter zarówno opisowy, jak i teoretyczny, a jej publiczny charakter jest ograniczony oraz c) wiedzę praktyczną, która służy działalności praktycznej zarówno podmiotów gospodarczych, jak i organizacji sektora publicznego (por. Chojnicki 1999, s. 92, 2001, s. 83). Wiedza naukowa o sektorze kreatywnym jest głównie wiedzą opisowo-informacyjną, a $\mathrm{w}$ aspekcie praktycznym $\mathrm{w}$ przeważającym stopniu jawną. Na tę ostatnią cechę wpływa fakt, że wiele badań przeprowadzanych jest lub inicjowanych przez władze publiczne, przez co wyniki tych badań stają się informacją publiczną. Szeroką dostępność do tej wiedzy umożliwiają publikacje za pośrednictwem Internetu oraz bazy danych. Służy ona głównie identyfikacji zjawisk i procesów oraz diagnozowaniu, w mniejszym zakresie pełniąc funkcje eksplanacyjne, $z$ uwagi m.in. na brak dobrych teorii. Natomiast samo wyjaśnianie zjawisk zachodzących $w$ ramach sektora kreatywnego odbywa się głównie na poziomie ekonomicznym, socjologicznym, geograficznym i kulturoznawczym, na którym poszukuje się mechanizmów kształtujących te zjawiska. Jeśli chodzi o funkcje praktyczne, to dotyczą one przede wszystkim kształtowania polityki miejskiej, regionalnej lub sektorowej albo innych działań władzy publicznej różnych szczebli - wiedza o sektorze kreatywnym służy za podstawę podejmowania decyzji, będących fundamentem polityki publicznej opartej na faktach i wiedzy naukowej (evidence-based policy) (szerzej zob. Harrison 2000, Sanderson 2002). Silne powiązania z praktyką, głównie z polityką publiczną, wynikają z ekonomiczno-politycznej genezy badań nad sektorem kreatywnym (por. ryc. 1). Ilczuk (2012) w swojej monografii na temat ekonomiki kultury dokonała klasyfikacji cytowanej bibliografii na:

1. Opracowania naukowe, których było 99 (46\% wszystkich cytowanych pozycji bibliograficznych).

2. Raporty i ekspertyzy - $76(35 \%)$.

3. Strony i portale internetowe $-17(8 \%)$.

4. Akty prawne $-23(11 \%)$.

To pokazuje, jak duży jest udział w badaniach naukowych opracowań wykonanych dla celów praktycznych, które stanowią najczęściej raporty przygotowywane 
przez firmy konsultingowe, organizacje pozarządowe, agendy rządowe itd. Wskazuje to jednak także na dużą rolę wiedzy pozanaukowej, nierzadko zakorzenionej w wiedzy potocznej, co może rzutować na jakość wyników badań nad sektorem kreatywnym. W literaturze zwraca się na ten problem uwagę, argumentując, że niejednokrotnie obraz sektora kreatywnego jest wyimaginowany, a przez to nierealny (Collis i in. 2010, 2013, Chapain i in. 2013). Innymi słowy, zbyt często źródłem poznania sektora kreatywnego jest rozum (racjonalizm), a nie doświadczenie (empiryzm) (szerzej o racjonalizmie i empiryzmie zob. Woleński 2007, s. 415-463).

Ad 3. W badaniach sektora kreatywnego przeważa podejście multidyscyplinarne, na które składają się przede wszystkim badania: ekonomiczne, socjologiczne, geograficzne, kulturoznawcze, ale nie brak także przedstawicieli szeregu innych dyscyplin. Multidyscyplinarność (wielodyscyplinarność) występuje wtedy, gdy pole badawcze zawiera pewną sumę składników różnych dyscyplin, które zachowują swoją indywidualność. Interdyscyplinarność stanowi natomiast wyższy poziom multidyscyplinarności, na którym różne dyscypliny dążą do uzyskania zintegrowanego ujęcia i wyników nie będących już tylko sumą poszczególnych rezultatów (szerzej zob. Thompson Klein 2010). Mimo odmienności celów, założeń i aparatury pojęciowej, a także metod badawczych oraz bazy faktograficznej, wyniki tych badań stworzyły wyodrębniony zasób wiedzy, która pełni przede wszystkim funkcje informacyjne dla rozwiązywania różnych problemów praktycznych. Jak dotychczas oprócz podejścia multidyscyplinarnego w badaniach sektora kreatywnego mały jest udział podejścia interdyscyplinarnego, który cechuje rozbudowa zintegrowanej problematyki i własnego aparatu pojęciowego oraz powstanie jedności koncepcyjnej pola badań. Badania takie miałyby prowadzić do wykrywania mechanizmów funkcjonowania i rozwoju sektora kreatywnego.

\section{Wnioski}

Można powiedzieć, że badania nad sektorem kreatywnym są in statu nascendi, choć $z$ drugiej strony ten stan kształtowania się trwa już około 20 lat (jeśli przyjąć za cezurę publikację australijskiego raportu „Creative nation” w 1994 r.), a w Polsce $\mathrm{z}$ pewnością ponad dekadę. Jeśli wliczyć $\mathrm{w}$ to badania $\mathrm{z}$ zakresu ekonomii kultury, to okres ten sięga półwiecza. $Z$ perspektywy historii nauki i ewolucji wiedzy naukowej nie jest to długi okres. Jednak zważywszy na trendy specjalizacyjne, możliwości technologiczne i dynamikę rozwoju współczesnej nauki, w której całe dyscypliny rozwijają się w ciągu kilkunastu lat, a ilość wytwarzanej wiedzy naukowej podwaja się co 10-20 lat (Weingart 2010), można powiedzieć, że badania sektora kreatywnego mają już pewną historię. Mimo to lata badań nadal nie pozwalają na wykrystalizowanie się względnie jednorodnej metodologiczne dziedziny. Wciąż jest wiele problemów z określeniem, czym jest sektor kreatywny, czego przykładem są niedookreślone znaczenia podstawowych pojęć. $Z$ jednej strony na taki stan rzeczy wpływa wielorakość ujęć tego, czym jest kultura i kreatywność, a $z$ drugiej jest to wynik multidyscyplinarnego charakteru badań, w któ- 
rych badacze z różnych dyscyplin wnoszą swoje tradycje metodologiczne, teorie, koncepcje i pojęcia. Wspólny aparat pojęciowy budowany jest często ad hoc, co przy globalnym obiegu idei skutkuje z jednej strony różnymi interpretacjami zakorzenionymi w lokalnych (narodowych) kulturach, a z drugiej - mechanicznymi tłumaczeniami podstawowych terminów, które wpływają na owe interpretacje (na co wskazano, pokazując problemy z polskimi tłumaczeniami). Podobnie jest z koncepcjami teoretycznymi, które nierzadko opierają się na wiedzy potocznej lub w sposób nadmiernie uproszczony próbują wyjaśniać zjawiska i procesy, na co zresztą krytycy różnych koncepcji, takich jak teoria klasy kreatywnej, zwracali już uwagę (zob. np. Peck 2005, Scott 2006, Pratt 2008b, Krätke 2010). Niemniej jednak żywe zainteresowanie problematyką sektora kreatywnego i duża liczba badań jemu poświęcona rozwija dynamicznie nowe podejścia i teorie. Przykładem może być koncepcja kapitalizmu kognitywno-kulturowego Scotta (2008, 2014), który za jej pomocą buduje fundament teoretyczny wyjaśniający głębsze mechanizmy stojące za współczesnym rozwojem i znaczeniem miast kreatywnych, sektora kreatywnego i gospodarki kreatywnej.

$\mathrm{Z}$ pewnością postęp w badaniach nad sektorem kreatywnym, jaki dokonany został $\mathrm{w}$ pierwszych piętnastu latach XXI w., należy uznać za znaczący. Pomimo, że wiedza na temat sektora kreatywnego jest już dobrze rozwinięta, ciągle odczuwalny jest niedostatek spójnych podstaw konceptualnych, który utrudnia badanie ogólniejszych zależności, np. jaką rolę sektor kultury odgrywa w rozwoju gospodarczym lub jakie są mechanizmy wpływu kultury na gospodarkę i odwrotnie. Być może jest to wynik sporów o sektor kreatywny. Czasem można odnieść wrażenie, że w kolejnych takich sporach - definicyjnych lub metodologicznych - znika gdzieś istota rzeczy. Przykładowo kreatywność jest punktem wyjścia większości rozważań i badań, a tymczasem mało kto rozważa, czy jest ona w ogóle cechą definicyjną sektora kreatywnego. Gdy się nad tym głębiej zastanowić, to może okazać się, że nie jest. Wszak kreatywność (jakkolwiek definiowana) jest obecna niemal we wszystkich dziedzinach życia, a nie tylko w tych, które zaliczane są do sektora kreatywnego (por. Sternberg, Lubart 1999, Nęcka 2001). Podobnie kreatywność nie jest differentia specifica kultury - w ponad 160 definicjach kultury zebranych przez Kroebera i in. (1952) jest ona wspomniana zaledwie w kilku (nie więcej niż pięciu). Na dodatek niektóre z definicji wprost wskazują, że kreatywność nie jest kluczowym elementem kultury. Na przykład niejaki Lowie w swej definicji z 1937 r. przez kulturę rozumie „sumę wszystkiego tego, co jednostka otrzymuje od społeczeństwa - wierzeń, zwyczajów, norm artystycznych, nawyków żywieniowych i sztuki rzemiosła, które docierają do niej nie przez jej własną twórczość [kreatywność], ale przez dziedzictwo przeszłości przekazywane w procesie edukacji, zarówno tej formalnej, jak i nieformalnej" (Kroeber i in. 1952, s. 43). Być może warto by w tej sytuacji przyjąć explicite, że termin „sektor kreatywny” i przez analogię wszystkie pokrewne terminy, takie jak „branża kreatywna”, „gospodarka kreatywna” itd., są pewnymi metaforami poznawczymi (por. Chojnicki 2003, s. 18-19) lub konwencjami terminologicznymi, a ich definicje mają charakter projektujący (por. Ziembiński 2002, s. 46). Sektor kreatywny byłby wtedy swoistym parasolem, pod którym gromadziłyby 
się podobne działalności, w dotychczasowych rozważaniach ekonomicznych pomijane lub uznawane za nieistotne.

Głównym wnioskiem, jaki nasuwa się po dokonanym przeglądzie problemów metodologicznych badania sektora kreatywnego, jest to, że do dalszego rozwoju tej dziedziny badań potrzebne jest skupienie się na budowie podstaw teoretycznych integrujących różne dotychczasowe ujęcia. Chodzi zatem o wypracowanie fundamentu badań, być może o interdyscyplinarnym charakterze. Moim zdaniem nie da się takiego fundamentu zbudować na gruncie empirycznym. Do tego potrzeba teorii, która stanowić będzie podstawowe narzędzie porządkowania i wyjaśniania faktów (por. Mould 2015). Chodzi tu więc o swego rodzaju teorię sektora kreatywnego. Ważną zaletą obecnego stanu badań jest to, że istnieje duża baza empiryczna wiedzy o sektorze kreatywnym. Badania nad różnymi aspektami sektora kreatywnego są prowadzone przy użyciu różnorodnego warsztatu metodologicznego, czasem dość wyrafinowanego. Dostarcza on sporej, ale jednak rozczłonkowanej wiedzy. Stosunkowo niewiele jest natomiast syntezy tego, co już wiemy o sektorze kreatywnym. Jest to zapewne rezultat pluralizmu metodologicznego, polegającego na stosowaniu w badaniach zarówno metod jakościowych, jak i ilościowych. Przy różnych założeniach i różnym statusie metodologicznym wykorzystywanych metod trudno porównywać ze sobą otrzymane wyniki badań. Szczególnie jeżeli wielu autorów ciągle próbuje od nowa definiować to, czym jest sektor kreatywny i jakie działalności są do niego zaliczane. Za tym bardziej wartościowe należy zatem uznać próby podejmowania badań na większą skalę (np. duże projekty międzynarodowe), z zastosowaniem ujednoliconych podejść i metod. W ostatnich latach pojawiały się też próby stworzenia syntetycznych opracowań lub podręczników (np. Towse 2010, 2011b, Andersson i in. 2011, Hartley i in. 2013, Jones i in. 2015), choć nie zawsze takich, które obejmują wszystkie aspekty zjawiska, a zwłaszcza jego podstawy teoretyczne. Przykładowo Malecki (2012) w recenzji „Handbook of creative cities” (Andersson i in. 2011) zarzuca, że jak na kompendium wiedzy o miastach kreatywnych zbyt wiele jest tam studiów przypadków, zresztą nierównomiernie dobranych, a niektóre części podręcznika są nadmiernie szczegółowe i techniczne. Według recenzenta należy oczekiwać, że podręcznik przedstawi aktualny stan wiedzy na konkretny temat, a nie tylko kolejny zbiór bardziej lub mniej tematycznie powiązanych studiów przypadków.

Wyraźne słabości metodologiczne badań sektora kreatywnego, na które zwrócono uwagę $\mathrm{w}$ artykule, to przede wszystkim: brak jedności terminologicznej i pojęciowej, niedostatek koncepcji teoretycznych, pluralizm metodologiczny i związane $z$ tym trudności interpretacyjne oraz ograniczone możliwości porównywania różnych wyników badań. Badania sektora kreatywnego mają jednak kilka atutów, z których najpoważniejszym jest innowacyjność podejmowanej problematyki, wynikająca m.in. z multidyscyplinarności badań i globalnego obiegu wiedzy. Należy oczekiwać, że badania te przejdą w fazę interdyscyplinarną, w której wypracowane są w miarę spójne metody i koncepcje, co pozwoli uzyskać wiedzę o głębszych mechanizmach funkcjonowania i rozwoju sektora kreatywnego. 


\section{Podziękowania}

\section{Autor składa podziękowania Paulinie Tomczak za pomoc w realizacji badań.}

\section{Literatura}

Adam J.H. 1989. Longman Dictionary of Business English. Longman, Harlow.

Adorno T.W. 2001. The culture industry: Selected essays on mass culture. Routledge, London, New York.

Andersson D.E., Andersson Å., Mellander C. 2011. Handbook of creative cities. Edward Elgar, Cheltenham.

Andres L., Chapain C. 2012. The integration of cultural and creative industries into local and regional development strategies in Birmingham and Marseille: Towards an inclusive and collaborative governance? Regional Studies, 47, 2: 161-182.

Bakhshi H., Hargreaves I., Mateos-Garcia J. 2013. A manifesto for the creative economy. Nesta, London.

Barnes T.J., Sheppard E. 2010. 'Nothing includes everything': Towards engaged pluralism in Anglophone economic geography. Progress in Human Geography, 34, 2: 193-214.

Baumol W.J., Bowen W.G. 1966. Performing arts - the economic dilemma: A study of problems common to theater, opera, music and dance. Twentieth Century Fund, Hartford.

Benjamin W. 1975. Dzieło sztuki w dobie reprodukcji technicznej. [W:] W. Benjamin (red.), Twórca jako wytwórca. Wydawnictwo Poznańskie, Poznań, s. 67-105.

Blaug M. 2001. Where are we now on cultural economics. Journal of Economic Surveys, 15, 2: 123143.

Brannen J. 2005. Mixing methods: The entry of qualitative and quantitative approaches into the research process. International Journal of Social Research Methodology, 8, 3: 173-184.

Bunge M. 2000. Systemism: The alternative to individualism and holism. Journal of Socio-Economics, 29, 2, s. $147-157$.

Caves R.E. 2000. Creative industries: Contracts between art and commerce. Harvard University Press, Cambridge.

Chapain C., Clifton N., Comunian R. 2013. Understanding creative regions: Bridging the gap between global discourses and regional and national contexts. Regional Studies, 47, 2: 131-134.

Chojnicki Z. 1999. Podstawy metodologiczne i teoretyczne geografii. Bogucki Wydawnictwo Naukowe, Poznań.

Chojnicki Z. 2001. Wiedza dla gospodarki w perspektywie OECD. [W:] A. Kukliński (red.), Gospodarka oparta na wiedzy. Wyzwanie dla Polski XXI wieku. KBN, Warszawa, s. 80-91.

Chojnicki Z. 2003. Koncepcje i zastosowania metafory w geografii społeczno-ekonomicznej. [W:] H. Rogacki (red.), Problemy interpretacji wyników metod badawczych stosowanych w geografii społeczno-ekonomicznej i gospodarce przestrzennej. Bogucki Wydawnictwo Naukowe, Poznań, s. $11-20$.

Chojnicki Z. 2010. Koncepcje i studia metodologiczne i teoretyczne w geografii. Bogucki Wydawnictwo Naukowe, Poznań.

Collis C., Felton E., Graham P. 2010. Beyond the inner city: Real and imagined places in creative place policy and practice. Information Society, 26, 2: 104-112.

Collis C., Freebody S., Flew T. 2013. Seeing the outer suburbs: Addressing the urban bias in creative place thinking. Regional Studies, 47, 2: 148-160.

Cooke P., Schwartz D. (red.) 2007. Creative regions: Technology, culture and knowledge entrepreneurship. Routledge, London.

Crative nation. 1994. Crative nation: Commonwealth cultural policy. Office for the Arts, Canberra.

Cunningham S. 2002. From cultural to creative industries: Theory, industry and policy implications. Media International Australia Incorporating Culture and Policy: Quarterly Journal of Media Research and Resources, 102: 54-65. 
Cunningham S. 2011. Developments in measuring the 'creative' workforce. Cultural Trends 20, 1, s. 25-40.

DCMS. 1998. Creative industries mapping document. Department for Culture, Media and Sport, London.

Fesel B., Söndermann M. 2007. Culture and creative industries in Germany. German Commission for UNESCO, Bonn.

Fierla I. 1974. Geografia przemysłu Polski. PWE, Warszawa.

Flew T. 2012. The creative industries: Culture and policy. Sage, London.

Florida R. 2002. The rise of the creative class: And how it's transforming work, leisure, community and everyday life. Basic Books, New York.

Galloway S., Dunlop S. 2007. A critique of definitions of the cultural and creative industries in public policy. International Journal of Cultural Policy, 13, 1: 17-31.

Garboua L., Montmarquette C. 1996. A microeconometric study of theatre demand. Journal of Cultural Economics 20, 1: 25-50.

Garnham N. 1987. Concepts of culture: Public policy and the cultural industries. Cultural Studies, 1, 1: 23-37.

Garnham N. 2005. From cultural to creative industries: An analysis of the implications of the "creative industries" approach to arts and media policy making in the United Kingdom. International Journal of Cultural Policy, 11, 1: 15-29.

Goodall B. 1987. The Penguin Dictionary of Human Geography. Penguin Books, London.

Gorynia M. 1993. Poziomy analizy w naukach ekonomicznych. Ekonomista, 4: 501-506.

Gorynia M., Jankowska B., Maślak E. 2000. Branża jako przedmiot badań w ekonomii. Gospodarka Narodowa, 3, s. 36-54.

GUS. 2014. Rocznik statystyczny przemysłu. Główny Urząd Statystyczny, Warszawa.

Harrison T. 2000. Urban policy: Addressing wicked problems. [W:] H.T.O. Davies, S.M. Nutley, P.C. Smith (red.), What works? Evidence-based policy and practice in public services. The Policy Press, Bristol, s. 207-228.

Hartley J. 2005. Creative industries. [W:] J. Hartley (red.), Creative industries. Blackwell, Malden, s. $1-40$.

Hartley J., Potts J., Cunningham S., Flew T., Keane M., Banks J. 2013. Key concepts in creative industries. Sage, London.

Henry C. (red.) 2007. Entrepreneurship in the creative industries: An international perspective. Edward Elgar, Cheltenham.

Hesmondhalgh D., Baker S. 2011. Creative labour: Media work in three cultural industries. Routledge, New York.

Hesmondhalgh D., Pratt A.C. 2005. Cultural industries and cultural policy. International Journal of Cultural Policy, 11, 1: 1-13.

Higgs P., Cunningham S., Bakhshi H. 2008. Beyond the creative industries: Mapping the creative economy in the United Kingdom. Nesta, London.

Horkheimer M., Adorno T.W. 1994. Dialektyka oświecenia. Fragmenty filozoficzne. Wydawnictwo IFiS PAN, Warszawa.

Howkins J. 2001. The creative economy: How people make money from ideas. Penguin, London.

Ilczuk D. 2012. Ekonomika kultury. PWN, Warszawa.

Janasz W. (red.) 1997. Podstawy ekonomiki przemysłu. PWN, Warszawa.

Jones C., Lorenzen M., Sapsed J. (red.) 2015. The Oxford handbook of creative industries. Oxford University Press, Oxford.

KEA. 2006. The economy of culture in Europe. KEA European Affairs, European Comission, Brussels.

Kielar B.Z. 1988. Tłumaczenie i koncepcje translatoryczne. Zakład Narodowy im. Ossolińskich, Wrocław.

Kłoskowska A. 1980/2005. Kultura masowa. Krytyka i obrona. PWN, Warszawa.

Kołakowski L. 2009. Główne nurty marksizmu. Tom 3. Rozkład. PWN, Warszawa.

Kopecka-Piech K. 2013. Spory o przemysły kreatywne. Kultura i Edukacja, 96, 3: 50-72.

Kortus B. 1986. Wstęp do geografii przemysłu. PWN, Warszawa.

Krätke S. 2010. 'Creative cities' and the rise of the dealer class: A critique of Richard Florida's approach to urban theory. International Journal of Urban and Regional Research, 34, 4: 835-853. 
Kroeber A.L., Kluckhohn C., Untereiner W., Meyer A.G. 1952. Culture. A critical review of concepts and definitions. The Museum, Cambridge, MA.

Landry C. 2000. The creative city: A toolkit for urban innovators. Earthscan, London.

Landry C., Bianchini F. 1995. The creative city. London, Demos.

Lange B., Bürkner H.-J. 2013. Value creation in scene-based music production: The case of electronic club music in Germany. Economic Geography, 89, 2: 149-169.

Lash S., Urry J. 1994. Economies of signs and space. Sage, London.

Łuczyński P. 2011. Słowa wyzbyte swych znaczeń. Czy warto angielskie terminy naukowe tłumaczyć na język polski? Nauka, 2, s. 131-141.

Mackiewicz M., Michorowska B., Śliwka A. 2009. Analiza potrzeb i rozwoju przemysłów kreatywnych. Raport końcowy. ECORYS, Warszawa.

Malecki E.J. 2012. Handbook of creative cities (book review). Regional Studies, 46, 8: 1102-1103.

Malinowski A. 1979. Szkoła frankfurcka a marksizm. PWN, Warszawa.

Markusen A., Schrock G. 2006. The artistic dividend: Urban artistic specialisation and economic development implications. Urban Studies, 43, 10: 1661-1686.

Martel F. 2008. Polityka kulturalna Stanów Zjednoczonych. Dialog, Warszawa.

Mould O. 2015. Seeking talent for creative cities: The social dynamics of innovation. Journal of Economic Geography, 15, 1: 247-249.

Musterd S., Bontje M., Chapain C., Kovács Z., Murie A. 2007. Accommodating creative knowledge: A literature review from a European perspective. ACRE report 1, AMIDSt, Amsterdam.

Nęcka E. 2001. Psychologia twórczości. Gdańskie Wydawnictywo Psychologiczne, Gdańsk.

Nowak S. 1985. Metodologia badań społecznych. PWN, Warszawa.

Nowicki W. 1986. Podstawy terminologii. Polska Akademia Nauk, Zakład Narodowy im. Ossolińskich, Wrocław.

OECD. 2007. Competitive cities: A new entrepreneurial paradigm in spatial development. OECD, Paris.

Payne G., Williams M., Chamberlain S. 2004. Methodological pluralism in British sociology. Sociology, 38, 1: 153-163.

Peck J. 2005. Struggling with the creative class. International Journal of Urban and Regional Research, 29, 4: 740-770.

Pierścionek Z. 2003. Strategie konkurencji i rozwoju przedsiębiorstwa. PWN, Warszawa.

Plum O., Hassink R. 2014. Knowledge bases, innovativeness and competitiveness in creative industries: the case of Hamburg's video game developers. Regional Studies, Regional Science, 1, 1: $248-268$.

Polak E., Polak W. 2013. Ekonomizacja nierynkowych dziedzin życia i jej konsekwencje. Współczesna Gospodarka, 4, 1: 11-20.

Pratt A.C. 1997. The cultural industries production system: A case study of employment change in Britain 1984-91. Environment and Planning A, 29, 11: 1953-1974.

Pratt A.C. 2005. Cultural industries and public policy: An oxymoron? International Journal of Cultural Policy, 11, 1: 31-44.

Pratt A.C. 2008a. Creative cities: The cultural industries and the creative class. Geografiska Annaler Series B: Human Geography, 90, 2: 107-117.

Pratt A.C. 2008b. Creative cities: The cultural industries and the creative class. Geografiska Annaler: Series B, Human Geography, 90, 2: 107-117.

Pratt A.C. 2008c. Cultural commodity chains, cultural clusters, or cultural production chains? Growth \& Change, 39, 1: 95-103.

Salanti A., Screpanti E. (red.) 1997. Pluralism in economics: New perspectives in history and methodology. Edward Elgar, Cheltenham.

Sanderson I. 2002. Evaluation, policy learning and evidence-based policy making. Public Administration, 80, 1: 1-22.

Scott A.J. 2004. Hollywood and the world: The geography of motion-picture distribution and marketing. Review of International Political Economy, 11, 1: 33-61.

Scott A.J. 2006. Creative cities: Conceptual issues and policy questions. Journal of Urban Affairs, 28, 1: $1-17$.

Scott A.J. 2008. Social economy of the metropolis: Cognitive-cultural capitalism and the global resurgence of cities. Oxford University Press, New York. 
Scott A.J. 2014. Beyond the creative city: Cognitive-cultural capitalism and the new urbanism. Regional Studies, s. 1-14.

Sechrest L., Sidani S. 1995. Quantitative and qualitative methods: Is there an alternative? Evaluation and Program Planning, 18, 1: 77-87.

Smoleń M. 2003. Przemysły kultury. Wpływ na rozwój miast. Wydawnictwo Uniwersytetu Jagiellońskiego, Kraków.

Spencer G. M. 2012. Creative economies of scale: An agent-based model of creativity and agglomeration. Journal of Economic Geography, 12, 1: 247-271.

Starr M. A. 2014. Qualitative and mixed-methods research in economics: Surprising growth, promising future. Journal of Economic Surveys, 28, 2: 238-264.

Sternberg R.J., Lubart T.I. 1999. The concept of creativity: Prospects and paradigms. [W:] R.J. Sternberg (red.), Handbook of creativity. Cambridge University Press, Cambridge, s. 3-15.

Stryjakiewicz T., Stachowiak K. 2010. Uwarunkowania, poziom i dynamika rozwoju sektora kreatywnego w poznańskim obszarze metropolitalnym. Bogucki Wydawnictwo Naukowe, Poznań.

Such J., Szcześniak M. 1997. Filozofia nauki. Wydawnictwo Naukowe UAM, Poznań.

Szomburg J. 2002. Kultura i przemysły kultury szansą rozwojową dla Polski. [W:] J. Szomburg (red.), Kultura i przemysły kultury szansą rozwojową dla Polski. Instytut Badań nad Gospodarką Rynkową, Gdańsk, s. 9-12.

Thompson Klein J. 2010. A taxonomy of interdisciplinarity. [W:] R. Frodeman, J. Thompson Klein, C. Mitcham (red.), The Oxford handbook of interdisciplinarity. Oxford University Press, Oxford, s. $15-30$.

Throsby D. 2008. Modelling the cultural industries. International Journal of Cultural Policy, 14, 3: $217-232$.

Tomczak P., Stachowiak K. 2015. Location patterns and location factors in the cultural and creative industries. Quaestiones Geographicae, 34, 2: 7-27.

Towse R. 2010. A textbook of cultural economics. Cambridge University Press, New York.

Towse R. 2011a. Ekonomia kultury. Kompendium. Narodowe Centrum Kultury, Warszawa.

Towse R. (red.) 2011b. A handbook of cultural economics. Edward Elgar, Cheltenham.

Trzeciak J. 2011. Ekonomika teatru. Instytut Teatralny im. Zbigniewa Raszewskiego, Warszawa.

UNDP, UNESCO. 2013. Creative economy report 2013. United Nations Development Programme, New York.

UNDP/UNCTAD. 2008. Creative economy. Report 2008. UNDP, UNCTAD, Geneva-New York.

UNESCO. 1982. Cultural industries: A challenge for the future of culture. UNESCO, Paris.

Weingart P. 2010. A short history of knowledge formations. [W:] R. Frodeman, J. Thompson Klein, C. Mitcham (red.), The Oxford handbook of interdisciplinarity. Oxford University Press, Oxford: $3-14$.

Woleński J. 2007. Epistemologia. Poznanie, prawda, wiedza, realizm. PWN, Warszawa.

Yeager C.D., Steiger T. 2013. Applied geography in a digital age: The case for mixed methods. Applied Geography, 39, 1: 1-4.

Ziembiński Z. 2002. Logika praktyczna. PWN, Warszawa.

\section{Methodological problems in the research on the creative sector}

Summary: The paper aims to identify and characterise the major methodological problems of the research on the cultural and creative industries. In the first part attention is paid to the problems associated with the semiotic issues, especially with the definitions, classification and translation. In the second part of the paper, the results of empirical research is presented. Body of work on cultural and creative industries were examined in detail. Focus was made on the methodologies used by various studies on cultural and creative industries. The outcome of this investigation have helped to characterise the main methodological features of research on the cultural and creative industries, such as the subject of the study, level of analysis, spatial scale, research methods, the type and source of the data used and the type of knowledge generated by this research.

Key words: creative industries, cultural industries, research methods 


\section{Załącznik}

\section{Wykaz prac, które zostały objęte badaniem}

1. AGERON Polska 2012. Analiza potencjalnych sektorów kreatywnych Mazowsza - wskazanie 5 najważniejszych sektorów/branż w aspekcie budowania inicjatyw klastrowych. Raport końcowy z badania. Urząd Marszałkowski Województwa Mazowieckiego, Warszawa.

2. Alfken C., Broekel T., Sternberg R. 2014. Factors explaining the spatial agglomeration of the creative class: Empirical evidence for German artists. European Planning Studies, s. 1-27.

3. Aluchna M., Fabrowska P., Kasprzak R., Skrobol M. 2012. Badanie sektora kreatywnego na potrzeby projektu European Creative Cluster Lab (ECCL). Raport początkowy. ECORYS, Warszawa.

4. Andres L., Chapain C. 2012. The integration of cultural and creative industries into local and regional development strategies in Birmingham and Marseille: Towards an inclusive and collaborative governance? Regional Studies, 47, 2: 161-182.

5. Aoyama Y. 2007. The role of consumption and globalization in a cultural industry: The case of flamenco. Geoforum, 38, 1: 103-113.

6. ASM - Centrum Badań i Analiz Rynku. 2014. Potencjały przemysłów kreatywnych w Łódzkim Obszarze Metropolitalnym. Łódź.

7. Atton C., McCleery A., Mabweazara H., Ward S. 2008. Creative futures: Building the creative economy through universities. Million+, London.

8. Awdziej M., Buchalska J., Czarkowska L., Dąbrowska K., Kaczmarek M., Kaczmarek-Kurczak P. i in. 2014. Oblicza kreatywności. Przedsiębiorczość w sektorach kreatywnych dla początkujących i zaawansowanych. Akademia Leona Koźmińskiego, Warszawa.

9. Bakhshi H., Hargreaves I., Mateos-Garcia J. 2013. A manifesto for the creative economy. Nesta, London.

10. Bakhshi H., McVittie E., Simmie J. 2008. Creating innovation: Do the creative industries support innovation in the wider economy?, Nesta, London.

11. Bayliss D. 2007. The rise of the creative city: Culture and creativity in Copenhagen. European Planning Studies, 15, 7: 889-903.

12. Bertacchini E.E., Borrione P. 2013. The geography of the Italian creative economy: The special role of the design and craft-based industries. Regional Studies, 47, 2: 135-147.

13. Boix R., Hervás-Oliver J.L., De Miguel-Molina B. 2014. Micro-geographies of creative industries clusters in Europe: From hot spots to assemblages. Papers in Regional Science (w druku).

14. Boix R., Lazzeretti L., Capone F., De Propris L., Sánchez D. 2013. The geography of creative industries in Europe: Comparing France, Great Britain, Italy and Spain. [W:] L. Lazzeretti (red.), Creative industries and innovation in Europe: Concepts, measures and comparative case studies. Routledge, London, s. 23-44.

15. Bontje M., Musterd S. 2009. Creative industries, creative class and competitiveness: Expert opinions critically appraised. Geoforum, 40, 5: 843-852.

16. Booyens I. 2012. Creative industries, inequality and social development: Developments, impacts and challenges in Cape Town. Urban Forum, 23, 1: 43-60.

17. Boschma R. A., Fritsch M. 2009. Creative class and regional growth: Empirical evidence from seven European countries. Economic Geography, 85, 4: 391-423.

18. Braun E., Lavanga M. 2007. An international comparative quick scan of national policies for creative industries. European Institute for Comparative Urban Research (EURICUR), Erasmus University, Rotterdam.

19. Brennan-Horley C. 2010. Mental mapping the 'creative city'. Journal of Maps, 6, 1: 250-259. 
20. Brennan-Horley C., Gibson C. 2009. Where is creativity in the city? Integrating qualitative and GIS methods. Environment and Planning A, 41, 11: 2595-2614.

21. Bronisz U. 2013. Znaczenie sektora kultury dla rozwoju społeczno-gospodarczego Lublina. [W:] A. Klasik (red.), Rozwój gospodarki kreatywnej na obszarach metropolitalnych. Wydawnictwo Uniwersytetu Ekonomicznego w Katowicach, Katowice, s. 134-142.

22. Budziński M. 2008. Potencjał sektora kultury w aglomeracji górnośląskiej. [W:] A. Klasik (red.), Aktywność przedsiębiorcza i konkurencyjność ekonomiczna miast w procesie restrukturyzacji aglomeracji miejskich. Wydawnictwo Akademii Ekonomicznej w Katowicach, Katowice, s. 78-94.

23. Building a digital economy: The importance of saving jobs in the EU's creative industries. 2010. TERA Consultants, Paris.

24. Catungal J.P., Leslie D. 2009. Contesting the creative city: Race, nation, multiculturalism. Geoforum, 40, 5: 701-704.

25. Chapain C., Comunian R. 2010. Enabling and inhibiting the creative economy: The role of the local and regional dimensions in England. Regional Studies, 44, 6: 717-734.

26. Christopherson S. 2006. Behind the scenes: How transnational firms are constructing a new international division of labor in media work. Geoforum, 37, 5: 739-751.

27. Christopherson S. 2008. Beyond the self-expressive creative worker: An industry perspective on entertainment media. Theory, Culture \& Society, 25, 7-8: 73-95.

28. Clare K. 2013. The essential role of place within the creative industries: Boundaries, networks and play. Cities, 34, 0: 52-57.

29. Clifton N. 2008. The "creative class" in the UK: An initial analysis. Geografiska Annaler, Series B, Human Geography, 90, 1: 63-82.

30. Clifton N., Cooke P. 2009. Creative knowledge workers and location in Europe and North America: A comparative review. Creative Industries Journal, 2, 1: 73-89.

31. Clifton N., Cooke P., Hansen H.K. 2010. Creative knowledge workers across 'varieties of capitalism': Evidence from Sweden and the UK. Pobrany 6.12.2014 ze strony http://www. regionalstudies.org/uploads/conferences/presentations/international-conference-2011/ clifton.pdf.

32. Clifton N., Cooke P., Hansen H.K. 2012. Towards a Reconciliation of the 'Context-less' with the 'Space-less'? The Creative Class across Varieties of Capitalism: New Evidence from Sweden and the UK. Regional Studies, 47, 2: 201-215.

33. Coe N.M. 2000. On location: American capital and the local labour market in the Vancouver film industry. International Journal of Urban and Regional Research, 24, 1: 79-94.

34. Cohendet P., Grandadam D., Simon L. 2010. The anatomy of the creative city. Industry and Innovation, 17, 1: 91-111.

35. Cole S. 2012. Creative chaos? Globalization, agglomeration and the metropolis. Journal of Economic Geography, 12, 6: 1217-1238.

36. Comunian R. 2011. Rethinking the creative city: The role of complexity, networks and interactions in the urban creative economy. Urban Studies, 48, 6: 1157-1179.

37. Comunian R., Chapain C., Clifton N. 2010. Location, location, location: Exploring the complex relationship between creative industries and place. Creative Industries Journal, 3, 1: 5-10.

38. Cunningham S. 2011. Developments in measuring the 'creative' workforce. Cultural Trends 20, $1: 25-40$.

39. Cunningham S., Higgs P. 2009. Measuring creative employment: Implications for innovation policy. Innovation: Management, Policy \& Practice, 11, 2: 190-200.

40. Currid E., Connolly J. 2008. Patterns of knowledge: The geography of avanced services and the case of art and culture. Annals of the Association of American Geographers, 98, 2: 414-434. 
41. Currid E., Williams S. 2010. Two cities, five industries: Similarities and differences within and between cultural industries in New York and Los Angeles. Journal of Planning Education and Research, 29, 3: 322-335.

42. Dahlström M., Hermelin B. 2007. Creative industries, spatiality and flexibility: The example of film production. Norsk Geografisk Tidsskrift - Norwegian Journal of Geography, 61, 3: $111-121$.

43. Davis C.H., Creutzberg T., Arthurs D. 2009. Applying an innovation cluster framework to a creative industry: The case of screen-based media in Ontario. Innovation: Management, Policy \& Practice, 11, 2: 201-214.

44. DCMS 2000. Creative industries: The regional dimension. The Report of the Regional Issues Working Group. Department for Culture, Media and Sport, London.

45. DCMS 2001. Creative industries mapping document. Department for Culture, Media and Sport, London.

46. DCMS 2008. Creative Britain: New talents for the new economy. Department for Culture, Media and Sport, London.

47. De Propris L., Chapain C., Cooke P., Mac Neill S., Mateos-Garcia J. 2009. The geography of creativity. Nesta, London.

48. De Propris L., Lazzeretti L. 2007. The Birmingham Jewellery Quarter: A Marshallian Industrial District. European Planning Studies, 15, 10: 1295-1325.

49. De Propris L., Wei P. 2009. Creativity and space: The opportunity of an urban creative jewellery cluster. Creative Industries Journal, 2, 1: 37-56.

50. Desrochers P., Leppälä S. 2011. Creative cities and regions: The case for local economic diversity. Creativity and Innovation Management 20, 1: 59-69.

51. Drake G. 2003. This place gives me space: Place and creativity in the creative industries. Geoforum, 34, 4: 511-524.

52. Drobniak A. 2008. Sektor kultury w procesie restrukturyzacji aglomeracji górnośląskiej. [W:] A. Klasik (red.), Aktywność przedsiębiorcza i konkurencyjność ekonomiczna miast w procesie restrukturyzacji aglomeracji miejskich. Wydawnictwo Akademii Ekonomicznej w Katowicach, Katowice, s. 94-112.

53. Drobniak A. 2014. Dynamika rozwoju sektora kreatywnego i jej wpływ na rozwój gospodarczy regionów i subregionów w Polsce południowej. [W:] A. Klasik (red.), Sektor kreatywny jako katalizator przemian strukturalnych w regionie. Wydawnictwo Uniwersytetu Ekonomicznego w Katowicach, Katowice, s. 121-143.

54. Drobniak A., Budziński M. 2008. Konkurencyjność ekonomiczna i aktywność przedsiębiorcza miast Aglomeracji Górnośląskiej oparta na sektorze i przemysłach kultury. Przypadek Katowic. [W:] A. Klasik (red.), Aktywność przedsiębiorcza i konkurencyjność ekonomiczna miast w procesie restrukturyzacji aglomeracji miejskich. Wydawnictwo Akademii Ekonomicznej w Katowicach, Katowice, s. 137-176.

55. Dudek-Mańkowska S., Fuhrmann M., Grochowski M., Zegar T. 2012. Sektor kreatywny a przestrzenie publiczne w Warszawie. Studia Regionalne, 11: 147-157.

56. ECORYS 2014. Branża przemysły kreatywne. Branżowy GPS dla absolwentów, Lublin-Warszawa.

57. Etmanowicz A., Trzebeński M., Martela B. 2012. Rekomendacje działań i kierunków wsparcia rozwoju przemysłów kreatywnych w województwie pomorskim. Podsumowanie prac grup ds. rekomendacji. Urząd Marszałkowski Województwa Pomorskiego, Gdańsk.

58. Evans G. 2009a. Creative cities, creative spaces and urban policy. Urban Studies, 46, 5-6: 1003-1040.

59. Evans G. 2009b. From cultural quarters to creative clusters: Creative spaces in the new city economy. [W:] M. Legner (red.), The sustainability and development of cultural quarters: International perspectives. Institute of Urban History, Stockholm, s. 32-59. 
60. Fesel B., Söndermann M. 2007. Culture and creative industries in Germany. German Commission for UNESCO, Bonn.

61. Flew T. 2013. Global creative industries. Polity Press, Cambridge.

62. Florida R. 2002. The rise of the creative class: And how it's transforming work, leisure, community and everyday life. Basic Books, New York.

63. Florida R. 2005a. Cities and the creative class. Routledge, New York.

64. Florida R. 2005b. The flight of the creative class: The new global competition for talent. Harper, New York.

65. Florida R., Mellander C., Stolarick K. 2008. Inside the black box of regional development - human capital, the creative class and tolerance. Journal of Economic Geography, 8, 5: 615-649.

66. Florida R., Tinagli I. 2004. Europe in the Creative Age. Demos, London.

67. Frenkel A., Bendit E., Kaplan S. 2013. Residential location choice of knowledge-workers: The role of amenities, workplace and lifestyle. Cities, 35: 33-41.

68. Friedrichs J. 1995. Cologne - a creative city. European Planning Studies, 3, 4: 441-463.

69. Gabe T.M. 2006. Growth of creative occupations in U.S. metropolitan areas: A shift-share analysis. Growth and Change, 37, 3: 396-415.

70. Gałka J., Grodny S., Olszewska D., Tompolska A. 2012. Potencjał małopolskich przemysłów kreatywnych. Urząd Marszałkowski Województwa Małopolskiego, Kraków.

71. Głowacki J. 2013. Przemysły kreatywne i ich wpływ na gospodarkę. [W:] J. Hausner, A. Karwińska, J. Purchla (red.), Kultura a rozwój. Narodowe Centrum Kultury, Warszawa, s. 435-454.

72. Grawon A., Klimas-Kuchta E., Małkiewicz E., Materska-Samek M., Potoczny J., Ulatowska R. 2012. Innowacje i nowe technologie przemysłów kreatywnych. Perspektywy rozwoju rynku audiowizualnego w Małopolsce. Fundacja Rozwoju Kina, Kraków.

73. Grochowski M. 2010. Sektor kreatywny w Warszawie. Potencjał i warunki rozwoju. Creative Metropoles, Warszawa.

74. Grochowski M., Dudek-Mańkowska S., Fuhrmann M., Zegar T. 2012. Sektor kreatywny w województwach pomorskim i kujawsko-pomorskim. Raport z badań. Agencja Rozwoju Pomorza, Gdańsk.

75. Grodach C. 2012. Before and after the creative city: The politics of urban cultural policy in Austin, Texas. Journal of Urban Affairs, 34, 1: 81-97.

76. Grodach C., Seman M. 2013. The cultural economy in recession: Examining the US experience. Cities, 33, 0: 15-28.

77. Hall P. 2000. Creative cities and economic development. Urban Studies, 37, 4: 639-649.

78. Hansen A.L., Andersen H.T., Clark E. 2001. Creative Copenhagen: Globalization, urban governance and social change. European Planning Studies, 9, 7: 851-869.

79. Hansen H.K., Niedomysl T. 2009. Migration of the creative class: Evidence from Sweden. Journal of Economic Geography, 9, 2: 191-206.

80. Hansen H.K., Winther L. 2010. The spatial division of talent in city regions: Location dynamics of business services in Copenhagen. Tijdschrift voor economische en sociale geografie, 101, 1: 55-72.

81. Heebels B., van Aalst I. 2010. Creative clusters in Berlin: Entrepreneurship and the quality of place in Prenzlauer Berg and Kreuzberg. Geografiska Annaler: Series B, Human Geography, 92, 4: 347-363.

82. Higgs P., Cunningham S., Bakhshi H. 2008. Beyond the creative industries: Mapping the creative economy in the United Kingdom. Nesta, London.

83. Hölzl K. 2006. Creative industries in Europe and Austria: Definition and potential. Austrian Institute for SME Research, Vienna. 
84. Hołda J., Zarębska-Denysiuk P., Celiński P., Kawa M., Hunkiewicz C., Sobczuk Z. 2012. Wsparcie przemysłów kreatywnych w Lublinie. Analiza potencjału i kierunki rozwoju. Lubelskie Towarzystwo Zachęty Sztuk Pięknych, Lublin.

85. Houston D., Findlay A., Harrison R., Mason C. 2008. Will attracting the "creative class" boost economic growth in old industrial regions? A case study of Scotland. Geografiska Annaler, Series B: Human Geography, 90, 2: 133-149.

86. Howkins J. 2001. The creative economy: How people make money from ideas. Penguin, London.

87. Hoyman M., Faricy C. 2009. It takes a village: A test of the creative class, social capital, and human capital theories. Urban Affairs Review, 44, 3: 311-333.

88. Hracs B.J. 2012. A creative industry in transition: The rise of digitally driven independent music production. Growth and Change, 43, 3: 442-461.

89. Hracs B.J., Grant J.L., Haggett J., Morton J. 2011. A tale of two scenes: Civic capital and retaining musical talent in Toronto and Halifax. Canadian Geographer / Le Géographe canadien, 55, 3: 365-382.

90. Ilczuk D. 2012. Ekonomika kultury. Wydawnictwo Naukowe PWN, Warszawa.

91. Ilczuk D., Krzysztofek K., Bender E., Nowak M., Wójcik A. 2011. Partnerstwa kreatywne w Polsce. Raport końcowy z badania. Narodowe Centrum Kultury, Warszawa.

92. Ilczuk D., Wieczorek A. 2000. On the development of cultural industries in post-communist Poland. Journal of Arts Management, Law \& Society, 30, 1: 53-64.

93. Jagodzińska K. 2013. Edukacja kulturalna na rzecz kreatywności i innowacyjności. [W:] J. Hausner, A. Karwińska, J. Purchla (red.), Kultura a rozwój. Narodowe Centrum Kultury, Warszawa, s. 327-343.

94. Jayne M. 2005. Creative industries: The regional dimension? Environment and Planning, C, 23, 4: 537-556.

95. Kamińska A., Lis M., Pogorzelski K. 2012. Mazowsze - region kreatywny? Instytut Badań Strukturalnych, Warszawa.

96. Kasprzak R. 2013. Przemysły kreatywne w Polsce. Uwarunkowania i perspektywy. Kamon Consulting, Warszawa.

97. Keane M. 2013. Creative industries in China: Art, design and media. Polity Press, Cambridge.

98. Kern J., Malinovsky J. 2009. Identyfikacja zalążków i procesów kreatywnych miast aglomeracji ostrawskiej. [W:] A. Klasik (red.), Kreatywne miasto - kreatywna aglomeracja. Wydawnictwo Akademii Ekonomicznej w Katowicach, Katowice, s. 95-110.

99. Klasik A. 2008. Wielkość i ranga miast aglomeracji górnośląskiej w aspekcie restrukturyzacji i tworzenia się nowej gospodarki. [W:] A. Klasik (red.), Aktywność przedsiębiorcza i konkurencyjność ekonomiczna miast w procesie restrukturyzacji aglomeracji miejskich. Wydawnictwo Akademii Ekonomicznej w Katowicach, Katowice, s. 52-77.

100. Klasik A. 2009. Przemysły kreatywne oparte na nauce i kulturze. [W:] A. Klasik (red.), Kreatywne miasto - kreatywna aglomeracja. Wydawnictwo Akademii Ekonomicznej w Katowicach, Katowice, s. 31-41.

101. Klasik A. 2010. Sektor kultury i przemysły kreatywne w rozwoju regionu na przykładzie aglomeracji górnośląskiej. Wydawnictwo Uniwersytetu Ekonomicznego w Katowicach, Katowice.

102. Knop L., Macełko M., Mendel I. 2011. Klastry kreatywne we współczesnych polskich realiach. Organizacja i Zarządzanie, 16, 4: 63-80.

103. Knudsen B., Florida R., Stolarick K., Gates G. 2008. Density and creativity in U.S. regions. Annals of the Association of American Geographers, 98, 2: 461-478.

104. Kopecka-Piech K. 2013a. Creative and cultural industries policy in Poland of 2012. Status, strategies and inaugurating projects. Transformacje (Transformations), 78-79, 3-4: 306-328. 
105. Kopecka-Piech K. 2013b. Spory o przemysły kreatywne. Kultura i Edukacja, 96, 3: 50-72.

106. Kopel A. 2007. Klasa kreatywna jako czynnik rozwoju miast. Zeszyty Naukowe Wyższej Szkoły Humanitas. Zarządzanie i Marketing, 1: 51-58.

107. Korcelli-Oiejniczak E., Kozłowski S.J. 2014. Sektor kreatywny w gospodarce ośrodków lokalnych jako czynnik kształtowania się regionu metropolitalnego Warszawy. [W:] A. Klasik (red.), Sektor kreatywny jako katalizator przemian strukturalnych w regionie. Wydawnictwo Uniwersytetu Ekonomicznego w Katowicach, Katowice, s. 175-190.

108. Koszarek M. 2010. Diagnoza sektora branż kreatywnych na obszarze Metropolii Gdańskiej. Raport końcowy. Gdańsk.

109. Kotylak S. 2013a. Przemysł kreatywny jako element gospodarki elektronicznej. Zeszyty Naukowe Uniwersytetu Szczecińskiego. Ekonomiczne Problemy Usług, 763, 105: 715-728.

110. Kotylak S. 2013b. Przemysł kreatywny jako element marketingu terytorialnego. Zeszyty Naukowe Uniwersytetu Szczecińskiego. Problemy Zarządzania, Finansów i Marketingu, 775, 30: 85-98.

111. Krätke S. 2010. 'Creative cities' and the rise of the dealer class: A critique of Richard Florida's approach to urban theory. International Journal of Urban and Regional Research, 34, 4: 835-853.

112. Krätke S. 2011. The creative capital of cities: Interactive knowledge creation and the urbanization economies of innovation. Wiley-Blackwell, Oxford.

113. Kwaśny J. 2012. Klasa kreatywna szansą na rozwój Tarnowa?! [W:] A. Klasik (red.), Kreatywna gospodarka w mieście i aglomeracji. Wydawnictwo Uniwersytetu Ekonomicznego w Katowicach, Katowice, s. 166-182.

114. Landry C. 2000. The creative city: A toolkit for urban innovators. Earthscan, London.

115. Lange B., Kalandides A., Stöber B., Mieg H.A. 2008. Berlin's creative industries: Governing creativity? Industry and Innovation, 15, 5: 531-548.

116. Lawton P., Murphy E., Redmond D. 2010. Examining the role of 'creative class' ideas in urban and economic policy formation: The case of Dublin, Ireland. International Journal of Knowledge-Based Development, 1, 4: 267-286.

117. Lawton P., Murphy E., Redmond D. 2013. Residential preferences of the 'creative class'? Cities, 31: 47-56.

118. Lazzeretti L., Boix R., Capone F. 2008. Do creative industries cluster? Mapping creative local production systems in Italy and Spain. Industry and Innovation, 15, 5: 549-567.

119. Lazzeretti L., Boix R., Capone F. 2009. Why do creative industries cluster? An analysis of the determinants of clustering of creative industries. IERMB Working Paper in Economics, Barcelona Institute of Regional and Metropolitan Studies, Barcelona.

120. Lazzeretti L., Capone F., Boix R. 2012. Reasons for clustering of creative industries in Italy and Spain. European Planning Studies 20, 8: 1243-1262.

121. Leslie D., Rantisi N.M. 2011. Creativity and place in the evolution of a cultural industry: The case of Cirque du Soleil. Urban Studies, 48, 9: 1771-1787.

122. Lewandowski P., Mućk J., Skrok Ł. 2010. Znaczenie gospodarcze sektora kultury. Wstęp do analizy problemu. Raport końcowy. Instytut Badań Strukturalnych, Warszawa.

123. Lipka A., Waszczak S. (red.) 2012. Ekonomia kreatywności. Jakość kapitału ludzkiego jako stymulator wzrostu społeczno-gospodarczego. Wydawnictwo Uniwersytetu Ekonomicznego w Katowicach, Katowice.

124. Long J. 2009. Sustaining creativity in the creative archetype: The case of Austin, Texas. Cities, 26, 4: 210-219.

125. Lorenzen M., Andersen K.V. 2007. The geography of the European creative class: A rank-size analysis. DRUID Working Paper, Frederiksberg.

126. Lorenzen M., Andersen K.V. 2009. Centrality and creativity: Does Richard Florida's creative class offer new insights into urban hierarchy? Economic Geography, 85, 4: 363-390. 
127. Lorenzen M., Andersen K.V. 2012. Different creative cities: Exploring Danish data to adapt the creative class argument to small welfare economies. Creative Industries Journal, 4, 2: 123-136.

128. Luckman S., Gibson C., Lea T. 2009. Mosquitoes in the mix: How transferable is creative city thinking? Singapore Journal of Tropical Geography, 30, 1: 70-85.

129. Ludwiczak A. 2014. Korzyści aglomeracji w otoczeniu sektora kultury. Współczesna Gospodarka, 5, 1: 57-66.

130. Mackiewicz M., Michorowska B., Śliwka A. 2009. Analiza potrzeb i rozwoju przemysłów kreatywnych. Raport końcowy. ECORYS, Warszawa.

131. Magda I., Sekuła E. A., Buchholtz S., Lewandowski P., Ośka M., Pospieszyńska-Burzyńska J. $\mathrm{i}$ in. 2012. Analiza potencjału rozwojowego funkcji metropolitalnych obszarów aglomeracji miejskich województwa śląskiego, będących ośrodkami wzrostu gospodarczego województwa śląskiego w kontekście procesów zachodzących na regionalnym rynku pracy - kultura i przemysły kreatywne. Raport końcowy. Instytut Badań Strukturalnych, Warszawa.

132. Malinovsky J. 2008. Innowacje i procesy innowacyjne w firmach miast Ostrawy i Frydka-Mistka. [W:] A. Klasik (red.), Aktywność przedsiębiorcza i konkurencyjność ekonomiczna miast w procesie restrukturyzacji aglomeracji miejskich. Wydawnictwo Akademii Ekonomicznej w Katowicach, Katowice, s. 323-340.

133. Markusen A. 2006. Urban development and the politics of a creative class: Evidence from a study of artists. Environment and Planning A, 38, 10: 1921-1940.

134. Markusen A., Schrock G. 2006. The artistic dividend: Urban artistic specialisation and economic development implications. Urban Studies, 43, 10: 1661-1686.

135. Markusen A., Wassall G.H., DeNatale D., Cohen R. 2008. Defining the creative economy: Industry and occupational approaches. Economic Development Quarterly, 22, 1: 24-45.

136. Martin-Brelot H., Grossetti M., Eckert D., Gritsai O., Kovács Z. 2010. The spatial mobility of the 'creative class': A European perspective. International Journal of Urban and Regional Research, 34, 4: 854-870.

137. Martin R., Moodysson J. 2011. Innovation in symbolic industries: The geography and organization of knowledge sourcing. European Planning Studies 19, 7: 1183-1203.

138. McCann E.J. 2007. Inequality and politics in the creative city-region: Questions of livability and state strategy. International Journal of Urban and Regional Research, 31, 1: 188-196.

139. McGranahan D., Wojan T. 2007. Recasting the creative class to examine growth processes in rural and urban counties. Regional Studies, 41, 2: 197-216.

140. Mellander C., Florida R. 2006. The creative class or human capital? Explaining regional development in Sweden. The Martin Prosperity Institute, Jönköping-Toronto.

141. Męczyński M. 2009. Miasto jako środowisko życia kreatywnych ludzi - przykład Poznania. [W:] A. Klasik (red.), Kreatywne miasto - kreatywna aglomeracja. Wydawnictwo Akademii Ekonomicznej w Katowicach, Katowice, s. 79-91.

142. Męczyński M. 2013. Znaczenie projektów wspierających rozwój sektora kreatywnego w podnoszeniu konkurencyjności wybranych regionów metropolitalnych Europy Zachodniej. [W:] A. Klasik (red.), Rozwój gospodarki kreatywnej na obszarach metropolitalnych. Wydawnictwo Uniwersytetu Ekonomicznego w Katowicach, Katowice, s. 23-45.

143. Montgomery L. 2010. China's creative industries: Copyright, social network markets and the business of culture in a digital age. Edward Elgar, Cheltenham.

144. Montgomery L., Fitzgerald B. 2006. Copyright and the creative industries in China. International Journal of Cultural Studies, 9, 3: 407-418.

145. Müller K., Rammer C., Trüby J. 2009. The role of creative industries in industrial innovation. Innovation: Management, Policy \& Practice, 11, 2: 148-168. 
146. Murzyn-Kupisz M. 2013. Potencjał „dzielnic kultury” we wzmacnianiu roli kultury w rozwoju ośrodka metropolitalnego. Doświadczenia Krakowa. [W:] A. Klasik (red.), Rozwój gospodarki kreatywnej na obszarach metropolitalnych. Wydawnictwo Uniwersytetu Ekonomicznego w Katowicach, Katowice, s. 101-122.

147. Musterd S., Deurloo R. 2006. Amsterdam and the preconditions for a creative knowledge city. Tijdschrift voor Economische en Sociale Geografie, 97, 1: 80-94.

148. Musterd S., Gritsai O. 2013. The creative knowledge city in Europe: Structural conditions and urban policy strategies for competitive cities. European Urban and Regional Studies 20, 3: 343-359.

149. Musterd S., Ostendorf W. 2004. Creative cultural knowledge cities: Perspectives and planning strategies. Built Environment, 30, 3: 189-193.

150. Namyślak B. 2009. Przemysły kreatywne w aglomeracji wrocławskiej. [W:] A. Klasik (red.), Kreatywne miasto - kreatywna aglomeracja. Wydawnictwo Akademii Ekonomicznej w Katowicach, Katowice, s. 123-131.

151. Namyślak B. 2010. Sektor kreatywny w gospodarce aglomeracji wrocławskiej. Wiadomości Statystyczne, 7: 36-47.

152. Namyślak B. 2013a. Miasto kreatywne w ujęciu teoretycznym. Studia Ekonomiczne i Regionalne, 6, 2: 5-21.

153. Namyślak B. 2013b. Ocena potencjału kulturalnego największych miast Polski. Wiadomości Statystyczne, 6: 23-38.

154. Namyślak B. 2013c. Zróżnicowanie poziomu rozwoju sektora kultury w miastach wojewódzkich w Polsce. Prace Geograficzne, 134: 101-120.

155. Namyślak B. 2014a. Ocena potencjału kulturalnego największych miast Polski w kategoriach: zasoby - aktywność - efekty rozwoju. Analiza taksonomiczna. [W:] A. Klasik (red.), Sektor kreatywny jako katalizator przemian strukturalnych $w$ regionie. Wydawnictwo Uniwersytetu Ekonomicznego w Katowicach, Katowice, s. 218-233.

156. Namyślak B. 2014b. Sektor kreatywny w gospodarce. Gospodarka Narodowa, 270, 2: 153-176.

157. Nesta. 2006. Creating growth: How the UK can develop world class creative businesses. NESTA Research Report. Nesta, London.

158. Newbigin J. 2010. Kreatywna gospodarka i przemysły kultury (creative and cultural economy). Cz. 1. Kreatywna gospodarka. Przewodnik dla początkujących. British Council, London.

159. O'Brien D. 2014. Cultural policy: Management, value and modernity in the creative industries. Routledge, Oxon.

160. Obłąkowska-Kubiak K. 2014. Sektor kultury i kreatywny jako wyzwanie dla małych i średnich przedsiębiorstw w Polsce. Studia Ekonomiczne Regionu Łódzkiego, 13: 33-45.

161. Olesiewicz K. 2011. Standaryzacja i rosnące znaczenie przemysłów kreatywnych na przykładzie segmentu komputerowych gier społecznościowych. Master of Business Administration, 162, 5: 114-128.

162. Peck J. 2005. Struggling with the creative class. International Journal of Urban and Regional Research, 29, 4: 740-770.

163. Pełka W. 2011. Sektor kreatywny jako katalizator wzrostu gospodarczego w krajach Europy Środkowej i Wschodniej. Збірник наукових праць Національного університету державної податкової служби України, 1: 842-849.

164. Piergiovanni R., Carree M., Santarelli E. 2012. Creative industries, new business formation, and regional economic growth. Small Business Economics, 39, 3: 539-560.

165. Podogrodzka M. 2012. Indeks Floridy 3T - talent. Propozycja korekty. [W:] A. Klasik (red.), Kreatywna gospodarka w mieście i aglomeracji. Wydawnictwo Uniwersytetu Ekonomicznego w Katowicach, Katowice, s. 65-79. 
166. Podogrodzka M. 2013a. Kapitał kreatywny a rozwój gospodarczy regionu w Polsce. Studia Ekonomiczne, 3: 417-440.

167. Podogrodzka M. 2013b. Klasa kreatywna a rozwój gospodarczy regionu w Polsce. Ekonomia (Economics), 24, 3: 106-118.

168. Podogrodzka M. 2014. Przestrzenne zróżnicowanie rozwoju gospodarczego Polski a klasa kreatywna. [W:] A. Klasik (red.), Sektor kreatywny jako katalizator przemian strukturalnych w regionie. Wydawnictwo Uniwersytetu Ekonomicznego w Katowicach, Katowice, s. 43-54.

169. Polko A., Wrana K. 2008. Konkurencyjność ekonomiczna i aktywność przedsiębiorcza miast aglomeracji górnośląskiej oparta na sektorze i przemysłach kultury. Przypadek Bytomia. [W:] A. Klasik (red.), Aktywność przedsiębiorcza i konkurencyjność ekonomiczna miast w procesie restrukturyzacji aglomeracji miejskich. Wydawnictwo Akademii Ekonomicznej w Katowicach, Katowice, s. 177-208.

170. Ponzini D., Rossi U. 2010. Becoming a creative city: The entrepreneurial mayor, network politics and the promise of an urban renaissance. Urban Studies, 47, 5: 1037-1057.

171. Potts J., Cunningham S. 2008. Four models of the creative industries. International Journal of Cultural Policy, 14, 3: 233-247.

172. Power D. 2002. "Cultural industries" in Sweden: An assessment of their place in the Swedish economy. Economic Geography, 78, 2: 103-127.

173. Power D. 2009. Culture, creativity and experience in Nordic and Scandinavian cultural policy. International Journal of Cultural Policy, 15, 4: 445-460.

174. Power D. 2011. Priority sector report: Creative and cultural industries. European Commission, Luxembourg.

175. Pożycka P. 2012a. Łódzki sektor kreatywny - ocena atrakcyjności miasta i potencjał sektora w świetle badań ankietowych środowiska kreatywnego. Uniwersytet Łódzki, Łódź.

176. Pożycka P. 2012b. Łódź - miasto kreatywne. Badanie potencjału kreatywnego Łodzi na tle wybranych miast Polski. Uniwersytet Łódzki, Łódź.

177. Przygodzki Z. 2014. Zróżnicowanie sektora kreatywnego w kontekście zdolności tworzenia miast kreatywnych w Polsce. [W:] A. Klasik (red.), Sektor kreatywny jako katalizator przemian strukturalnych w regionie. Wydawnictwo Uniwersytetu Ekonomicznego w Katowicach, Katowice, s. 157-174.

178. Puchta D., Schneider F., Haigner S., Wakolbinger F., Jenewein S. 2010. The Berlin creative industries: An empirical analysis of future key industries. Gabler, Wiesbaden.

179. Ratzenböck V., Demel K., Harauer R., Landsteiner G., Falk R., Leo H. i in. 2004. An analysis of the economic potential of the creative industries in Vienna. Österreichische Kulturdokumentation, MEDIACULT and Wifo, Vienna.

180. Rollnik-Sadowska E., Szlis I. 2013. Strategia partnerstwa na rzecz rozwoju polskiego przemysłu kreatywnego. Towarzystwo Amicus, Warszawa-Białystok.

181. Rozentale I. 2014. Creative industries during economic recession: The case of Riga. Regional Studies, Regional Science, 1, 1:329-335.

182. Rudawska I., Bąkowska S. 2012. Wartość relacji władze samorządowe - klasa kreatywna. Empiryczna weryfikacja modelu. Ruch Prawniczy, Ekonomiczny i Socjologiczny, 4: 163-180.

183. Rumpel P., Slach O., Koutský J. 2010. Creative industries in spatial perspective in the old industrial Moravian-Silesian Region. Ekonomie a Management, 4: 30-46.

184. Sagan M., Trojanowski K. 2014. Klasy kreatywne w Strategii Lublin 2020. Zeszyty Naukowe WSEI seria: Ekonomia, 8, 1:315-324.

185. Scott A.J. 2014. Beyond the creative city: Cognitive-cultural capitalism and the new urbanism. Regional Studies, s. 1-14.

186. Slach O., Koutský J., Novotný J., Ženka J. 2013. Creative industries in the Czech Republic: A spatial perspective. Ekonomie a Management, 16, 4: 14-29.

187. Smoleń M. 2003. Przemysły kultury. Wpływ na rozwój miast. Wydawnictwo Uniwersytetu Jagiellońskiego, Kraków. 
188. Söndermann M., Backes C., Arndt O., Brünink D. 2009. Culture and creative industries in Germany: Defining the common characteristics of the heterogeneous core branches of the "cultural industries" from a macro-economic perspective.

189. Spencer G.M. 2012. Creative economies of scale: An agent-based model of creativity and agglomeration. Journal of Economic Geography, 12, 1:247-271.

190. Stam E., De Jong J.P.J., Marlet G. 2008. Creative industries in the Netherlands: Structure, development, innovativeness and effects on urban growth. Geografiska Annaler: Series B: Human Geography, 90, 2: 119-132.

191. Stryjakiewicz T. 2010. Location factors od the creative and knowledge-intensive industries in European metropolitan regions. Geografický Časopis, 62, 1: 3-19.

192. Stryjakiewicz T., Męczyński M., Stachowiak K. 2009. Sektor kreatywny w poznańskiej gospodarce. Uniwersytet im. Adama Mickiewicza w Poznaniu, Poznań.

193. Suchta J., Cellmer A., Jasiński J. 2012. Rozwój społeczno-gospodarczy Olsztyna jako efekt działalności sektorów kreatywnych. [W:] A. Klasik (red.), Kreatywna gospodarka w mieście i aglomeracji. Wydawnictwo Uniwersytetu Ekonomicznego w Katowicach, Katowice, s. 155-165.

194. Szultka S. 2014. Kreatywny łańcuch - powiązania sektora kultury i kreatywnego w Polsce. Instytut Badań nad Gospodarką Rynkową, Gdańsk.

195. Szultka S. (red.) 2012. Klastry w sektorach kreatywnych - motory rozwoju miast i regionów. Polska Agencja Rozwoju Przedsiębiorczości, Warszawa.

196. Toruńska Agencja Rozwoju Regionalnego. 2012. Rekomendacje działań i kierunków wsparcia rozwoju dla sektora kreatywnego w województwie kujawsko-pomorskim. Torun.

197. Tschmuck P. 2003. How creative are the creative industries? A case of the music industry. The Journal of Arts Management, Law, and Society, 33, 2: 127-141.

198. Turok I. 2003. Cities, clusters and creative industries: The case of film and television in Scotland. European Planning Studies, 11, 5: 549-565.

199. UNDP, UNESCO 2013. Creative economy report 2013 - special edition: Widening local development pathways. United Nations Development Programme, New York.

200. UNDP/UNCTAD 2008. Creative economy. Report 2008. UNDP, UNCTAD, Geneva-New York.

201. Urząd Miejski w Gdańsku. 2012. Sektor kreatywny w Gdańsku - potencjał i możliwości rozwoju. Gdańsk.

202. Verdich M. 2010. Creative migration? The attraction and retention of the 'creative class' in Launceston, Tasmania. Australian Geographer, 41, 1: 129-140.

203. Waitt G., Gibson C. 2009. Creative small cities: Rethinking the creative economy in place. Urban Studies, 46, 5-6: 1223-1246.

204. White P. 2010. Creative industries in a rural region. Creative West: The creative sector in the Western Region of Ireland. Creative Industries Journal, 3, 1: 79-88.

205. Wolny Z., Piszczek R., Kempa A., Tkocz-Piszczek E., Olcha B., Chmiel K. 2012. Raport końcowy: Pilotażowe badania rozpoczynające proces długoletniego monitorowania zachodniopomorskiego rynku przemysłów kreatywnych. Urząd Marszałkowski Województwa Zachodniopomorskiego, Rybnik.

206. Zakrzewska-Półtorak A. 2012. Integracja aglomeracji wrocławskiej a działalności kreatywne. [W:] A. Klasik (red.), Kreatywna gospodarka w mieście i aglomeracji. Wydawnictwo Uniwersytetu Ekonomicznego w Katowicach, Katowice, s. 139-154.

207. Zarząd Województwa Zachodniopomorskiego 2013. Program strategiczny: Przemysły kreatywne i przemysły czasu wolnego. Szczecin.

208. Zawadzki K. 2013. Zatrudnienie w wybranych sektorach i zawodach kreatywnych w Unii Europejskiej w okresie kryzysu gospodarczego. Specyfika i perspektywy wzrostu. Optimum. Studia Ekonomiczne, 66, 6: 57-69.

209. Żurawicz A. 2010. Kinematografia w Polsce. Wiadomości Statystyczne, 7: 23-36. 